Geological Society, London, Special Publications

\title{
Mylonites: lessons from Eriboll
}

S. H. White

Geological Society, London, Special Publications 2010, v.335; p505-542.

doi: $10.1144 /$ SP335.22

Email alerting

service

Permission

request

Subscribe click here to receive free e-mail alerts when new articles cite this article

click here to seek permission to re-use all or part of this article

click here to subscribe to Geological Society, London, Special Publications or the Lyell

Collection

\section{Notes}

(C) The Geological Society of London 2012 


\title{
Mylonites: lessons from Eriboll
}

\author{
S. H. WHITE \\ Honorary Research Fellow, School of Earth Sciences, University of Melbourne, Australia. \\ Also, Professor Emeritus, Department of Earth Sciences, Faculty of Geosciences, \\ Utrecht University, The Netherlands (e-mail: stan.white@bigpond.com)
}

\begin{abstract}
Eriboll has been an important area in understanding the geology and structure of the NW Highlands of Scotland. It came to prominence during the Highland Controversy between Nicol and Murchison in the 1850s. Nicol recognized a major regional, or grand, dislocation (the Moine Thrust Zone) at Eriboll whereas Murchison denied its existence. An important element in the resolution of the controversy was the repeated observation of a distinctive schistose rock that often marked Nicol's dislocation. Lapworth named it a 'mylonite' and related its development to mechanical metamorphism resulting from tectonic (milling) movements along the dislocation. Peach, Horne and co-workers, whose contributions to early mylonite studies are often overlooked, described the effects of increasing strain on mylonite development, recorded the prominent lineation within mylonites and identified its kinematic significance via thrust geometries and a first use of shear sense indicators. In this contribution those elements of the Highland Controversy that led to the identification of mylonites will be reviewed, concentrating on the contributions of Lapworth and of Peach, Horne and co-workers. It will include an examination and discussion of the mylonites from Lapworth's locality and of the mylonitized Moine schists at Eriboll. It will conclude with comments on mylonite classification and nomenclature.
\end{abstract}

The first use of the term 'mylonite' was by Lapworth $(1885 a)$ for a distinctive suite of foliated rocks that he observed associated with a major overthrow fault (thrust) at Ben Arnaboll in the Eriboll area of NW Scotland (see Figs $1 \& 2$ ). The overthrow fault had been first identified by Nicol (1860) as a major regional or grand dislocation in rocks that Murchison $(1858 a, b)$ had described as a continuous succession of Silurian sediments albeit the farther one went to the east the more metamorphosed the sediments became. The grand dislocation mapped by Nicol (1860) would become known as the Moine Thrust Zone (Fig. 1). However, this was after it had become the focus for the Highland Controversy (Oldroyd 1990). It should be remembered that in the mid-19th century, geologists used the term 'dislocation' as we would use 'fault' today (see the textbooks by Page 1870, 1877).

The Highland Controversy arose from the conflicting views of Murchison and Nicol. It formed the third of the three controversies involving Murchison that contributed to the founding of modern British geology. All centred on the assignment of rocks to Murchison's Silurian System (Murchison $1839,1854)$. The disputed position of the upper boundary of the Silurian System led to the controversy between Murchison and de la Beche (Rudwick 1985) and of the lower boundary to the controversy between Murchison and Sedgwick (Secord 1986); both have also been reviewed by Bassett (1991). For the purposes of this paper it is worth recalling that through Lapworth's attention to the Murchison-Sedgwick controversy, there arose the Ordovician System (Lapworth 1878, 1879) and, of importance to structural geology, the introduction of detailed regional structural mapping at the scale of six inches to the mile, using Ordinance Survey maps as a base (see below).

The geo-political aspects of the Highland Controversy have been detailed by Oldroyd (1990). Pertinent geological aspects will be reviewed briefly in this article. Attention will be given to the rock that Nicol had noted commonly occurred between the overlying eastern gneisses (Moine schists in modern terminology) and the underlying quartzite- limestone sequence (Cambro-Ordovician sediments) which, at Eriboll, unconformably overlay the western or Hebridean (Lewisian) gneisses. Although we now know that this rock is a tectonically emplaced sliver of Lewisian gneiss, its origin, the deformation induced textural and petrological changes within it and its structural position were the bases for critical arguments that ended the Highland Controversy. From studies of this rock, there emerged an appreciation of the effects of deformation on rocks and this, in turn, led to the identification of a mylonite, and a first appreciation of the deformation and metamorphic processes that can produce a mylonite. The contributions of Lapworth $(1883,1884,1885 a, b)$ and of Peach \& Horne $(1884,1885)$, together with other members of the British Geological Survey team (Peach 


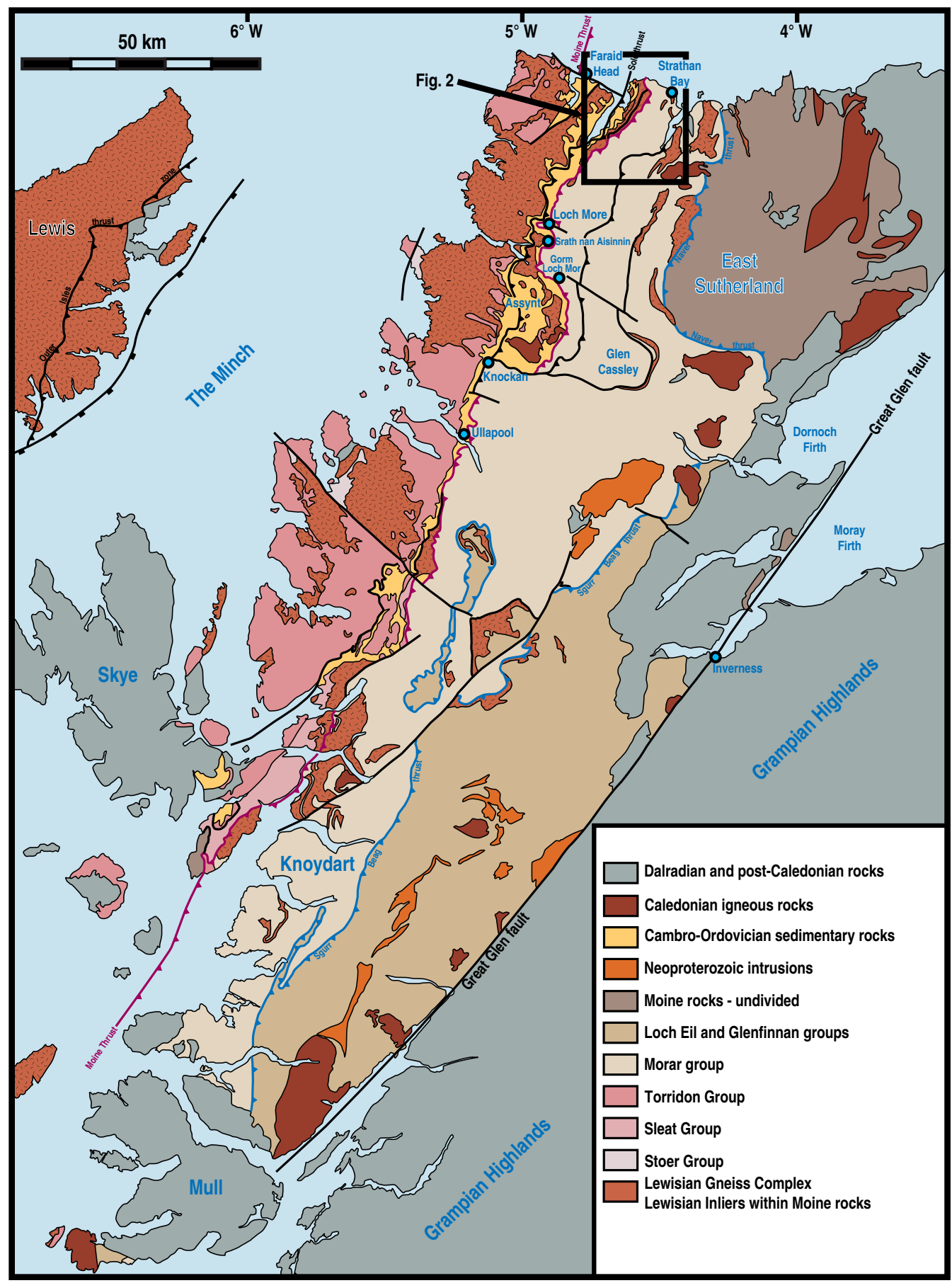

Fig. 1. Geological map of NW Scotland showing the Moine Thrust Zone, the Ben Hope Slide or Thrust, the Sgurr Beag-Naver Slide or Thrust and the Great Glen Fault (GGF). (Supplied by Ryan Thigpen, modified from Krabbendam et al. 2008; also see Thigpen et al. 2010.) 


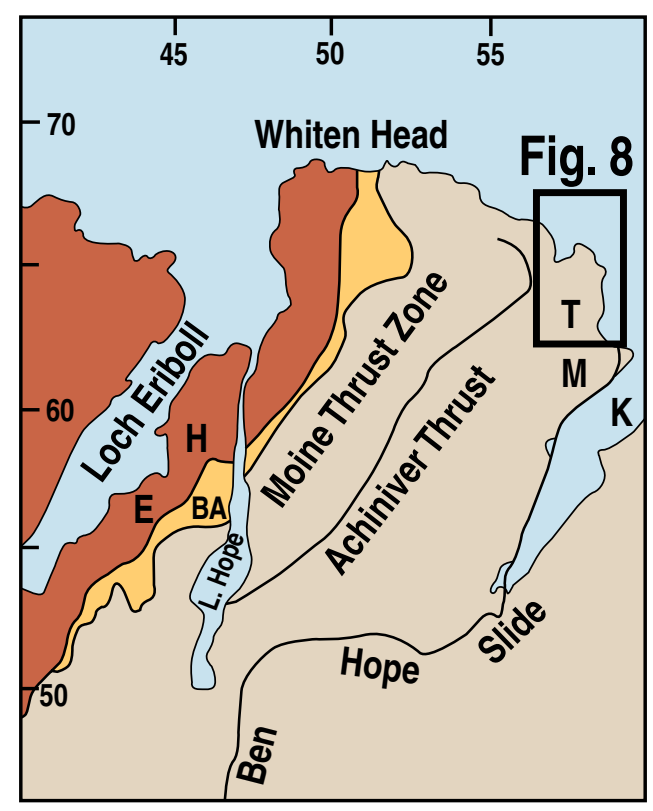

Fig. 2. A sketch map of the Eriboll area, as indicated in Figure 1, showing the position of the Moine Thrust Zone, Achiniver (Halfway House) Thrust (Slide), and the Ben Hope Slide (Thrust). E, Eriboll; H, Heilam; BA, Ben Arnaboll; T, Talmine; M, Melness; K, Kyle of Tongue. (Supplied by Ryan Thigpen, based on Krabbendam et al. 2008, also see Thigpen et al. 2010.)

et al. 1888) led to the structural unravelling of the Eriboll area and the subsequent closure of the Highland Controversy.

The above research also revealed the important role that mylonites can play in the structural evolution of a highly deformed area and laid the foundations for our understanding of how rocks deform to large strains within shear zones during a natural deformation. These are the topics reviewed in this contribution and which will include a look at the mylonites from Lapworth's locality at Ben Arnaboll and from within the nearby Moine schists; both in the Eriboll area (see Fig. 2). This article will conclude with comments on mylonite nomenclature and classification.

\section{Geological observations leading to the Highland Controversy}

Murchison first went to the NW Highlands with Sedgwick in 1827 (Murchison 1858b). He returned to the area in 1855 accompanied by Nicol (Nicol 1856). Initial harmony between Murchison and Nicol was replaced by controversy which resulted in both going their separate geological ways. Nicol published his interpretations of the geology of the NW Highlands in 1856 (Nicol 1856), his map in 1858 (Nicol 1858) and the structure of the area in 1860 (Nicol 1860).

Murchison gave a summary of his findings in an abstract published in early 1858 (Murchison 1858a) and published his detailed interpretations later that year (Murchison 1858b). His findings were best summarized in a cross-section corresponding to the northern coastline of Scotland. He showed a continuous section of lower Silurian sediments overlying red sandstones and conglomerates, which he thought were Cambrian, or elsewhere overlying the basement (western) gneisses in the west, and being overlain by the Devonian Old Red Sandstone in the east. Murchison noted that his Silurian sequence became metamorphosed to the east. He argued that the contact between the non-metamorphosed and metamorphosed sediments was a conformable sedimentary contact with the increase in metamorphic grade being due to the heating induced by intrusions, many of which were conformable. He explained the foliation in the upper (eastern) gneisses as being

nothing more than the original laminae of deposit under water... which have been so altered as often to segregate in one layer more mica, more sand or clay, thus evolving feldspathic, quartzose and mica crystalline laminae (Murchison \& Geikie 1861b).

In contrast, Nicol thought the contact was tectonic.

Murchison had knowledge of the contents of Nicol's 1860 paper for in his diagrammatic crosssection from Eriboll to Tongue (Murchison 1858b) he noted that Nicol had observed a band of porphyry along the contact between the non-metamorphosed quartzite-limestone sequence and the upper metamorphics (upper or eastern gneisses). He also knew that Nicol considered that the contact was the site of a grand dislocation, that is, the juxtaposition was, according to Nicol, tectonic and not sedimentary. Murchison did not deny the existence of a dislocation or dislocations along the contact between the quartzite-limestone sequence and the upper gneisses. He recorded that stratified rocks associated with the contact were 'highly altered and dislocated' and that syenitic and porphyritic rocks 'protruded' from the contact zone (Murchison $1858 b$, figs $1 \& 8)$. He regarded the alteration, the dislocations and the presence of igneous rocks along the contact as being local phenomena that had not affected the stratigraphic order and this formed the basis for his rejection of Nicol's proposal that the contact was tectonic. Murchison went on to refute Nicol's interpretation strongly in a footnote in his 1858 paper (Murchison 1858b) and continued this refutation in three papers published both before (Murchison 1859) and after (Murchison \& Geikie $1861 a, b)$ the publication of Nicol's 1860 paper. 
Nicol (1860) concluded that 'the line of junction, where this conformable succession is said to occur, is clearly a line of fault, everywhere indicated by proofs of fracture, contortion of the strata, and powerful igneous action'. His section from Loch Eriboll, via Heilam, to Loch Hope (see Fig. 2 for locations) shows an intrusive rock along the contact at Ben Arnaboll and he recorded that in places it appeared to be a granite, a feldspar porphyry or diorite, finally settling on the term 'granulite'. He noted (Nicol 1860) that Cunningham in his 1839 paper thought that this rock was a gneiss. Nicol (1860) went on to say that the western gneiss was repeated in the eastern gneisses, but possibly because of its tectonically induced alteration and textural modification, he did not associate the granulite with the western gneiss. He also observed, in the vicinity of Eriboll farm, overturning of the quartzite-limestone sequence under the eastern schists and recorded that a relationship between synclines and faults ('faulted synclinals') was a common feature in Sutherland and which often led to a repetition or deletion of stratigraphy.

Nicol (1860) traced the faulted contact between the quartzite-limestone sequence and the upper or eastern gneisses from Whiten Head in the north through Eriboll to Glencoul and Assynt, on to Graig-a-Chnockan (Knockan), Ullapool, Loch Maree and onward to Loch Carron and Skye (see Figs $1 \& 2$ ), that is, for over 100 miles. He referred to the faulted contact as 'a grand dislocation'. Nicol was unsure of the age of the upper gneiss but speculated that it could, in part, be similar to the western gneiss. Irrespective of its age, Nicol concluded that the upper gneiss had been forced up and over the quartzite-limestone sequence during a violent convulsion and noted that the sections produced 'are clear and simple and quite analogous to those produced in other mountain-regions' (Nicol 1860). He went on to liken the process to that which formed the Alps (Nicol 1860), quoting that 'the strata had been inverted, not by frequent folds but in one enormous overthrow, so that over a wide horizontal area, the uppermost strata' which may have been folded 'were covered by the lateral extrusion over them of older and more crystalline masses'. The words which he quoted were from Murchison's extensive paper on the structure of the Alps (Murchison 1848). The enormous overthrow, that Murchison had figured and described in that paper, was the Glarus Thrust (see review by Bailey 1935). It would appear that Murchison was either unable to see the structural similarities between the Alps and NW Scotland, a point also made by Bailey (1935), or was unable to admit he had been checkmated by Nicol.

Murchison revisited much of the NW Highlands in the company of Ramsay in 1859 and showed that an intrusive rock was frequently associated with the contact between the quartzite-limestone sediments and the overlying flaggy or gneissose (eastern) schists (Murchison 1859). He demonstrated this association in a sketched section across the Ben Arnaboll area at Eriboll (Murchison 1859, fig. 10). Murchison concluded that "no great line of dislocation separates the upper quartzites and limestones from the so-called gneiss'. Murchison (1859) did not say that there was no dislocation separating the quartzites and limestones from the gneiss but that there was 'no great line of dislocation' of the type that would affect his order of stratigraphy.

Murchison extended his fieldwork to the south in the following year but was accompanied not by Ramsay, who had taken ill, but by Geikie (Geikie 1924). Geikie (1924) wrote that he was unexpectedly called, in the autumn of 1860 , from his field mapping in East Lothian to join Murchison as a replacement for Ramsay. Although Geikie felt that he was ill-equipped to work among the crystalline schists he accepted Murchison's invitation. According to Geikie the purpose of the field work was to continue Murchison's identification of Silurian rocks to areas of the Highlands that Murchison had not visited (Geikie 1924), although, as will be discussed below, Nicol's dislocation was on Murchison's mind. The time spent in the Highlands in 1860 had a significant social element as Murchison renewed old acquaintances (see Geikie 1924).

One reason for Murchison to select Geikie was Geikie's knowledge of the geology of the southern areas of Scotland (see Murchison in Murchison \& Geikie 1862). By pooling their combined knowledge, they were able to produce their geological map of Scotland (Murchison \& Geikie 1862) four years after Nicol's map appeared (Nicol 1858). It should not be forgotten that the six inch to the mile Ordnance Survey maps for much of the southern part of Scotland were published during the 1850s (see Fleet \& Withers 2008) enabling accurate regional mapping to be undertaken. Geikie started mapping in the Mid and West Lothian and Edinburghshire areas in 1855 using the earliest Scottish Ordnance Survey maps (Geikie 1924) which were published in 1854 (see Fleet \& Withers 2008). Initially there were only two geologists in the Edinburgh office of the Geological Survey, Geikie and one other who was mapping the Mid Lothian and Fife coalfields. When the coalfields project was completed, Geikie became the sole representative of the Geological Survey in Scotland for some time (Geikie 1924). Another reason for Murchison selecting Geikie may well have been that he was the only Scottish geologist available. As Geikie (1924) remarked, the choice of his initial mapping areas were defined by the presses of the Ordnance Survey. He added that 
winter did not interfere with mapping until 1858 when he began to spend a part of each winter in the London office drafting his maps; he had no drafting support in Edinburgh. By the time Geikie received his call from Murchison in 1860, he would have been the most experienced geologist in the Survey with respect to detailed regional mapping in Scotland. Ordnance Survey maps (six inch scale) were not available for the Highlands and Islands until $c$. 1880 with contoured maps, at the one inch scale, following soon after (see Fleet $\&$ Withers 2008). The exceptions were those maps covering Lewis; the six inch scale maps were published in 1854 and the one inch scale in 1858 . Consequently, regional field work in the Highlands prior to 1880 was of a reconnaissance nature with reliance on sketches and sections and this is what Murchison and Geikie undertook in 1860.

It is interesting to note that, as a result of their field studies in 1860, Murchison \& Geikie (1861a) did show a serpentinous and a feldspathic rock lying along the junction between the limestone and the overlying flaggy schists at the base of the eastern gneisses. Murchison named the lower gneiss 'Lewisian' and again argued that this was not repeated in the flaggy schists as suggested by Nicol (Murchison 1859; Murchison \& Geikie 1861a). Murchison continued his attack on Nicol's work with his firm statement that the quartzitelimestone and upper (eastern) gneisses form a 'regular and unbroken ascending order' and that there is neither repetition within the quartzitelimestone sequence nor Lewisian gneiss within the upper gneisses (Murchison \& Geikie 1861a). Above all, there was no regional scale dislocation. Not only could he (Murchison) find no evidence for any dislocation, he stated (see appendix in Murchison \& Geikie 1861a) 'Mr Geikie has followed its disputed line of the junction from Sutherland through mountainous tracts of Ross-shire for more than sixty miles' and in spite of many traverses across that line, found no trace of it. It is interesting to note that Geikie (1884) wrote that he had not seen the Eriboll section, which was the most contentious and most accessible in Sutherland, prior to 1884. Geikie's traverses, referred to above by Murchison, were undertaken because Murchison, in 1860, was unable to walk over rough or hilly country, a further reason for selecting a young assistant (Geikie 1924). Geikie's traverses were limited to the area between Loch Hourne and Ullapool. The final 32 miles from Loch Maree to Ullapool were walked across country by Geikie, accompanied by a local guide, in a day (Geikie 1924). This walk was repeated, in more recent times, by Butler and colleagues (see account by Butler 2000).

At Kinlochewe, Geikie found 'great dislocations by which the dull red sandstone and its overlying white quartzite were thrown into inverted positions'. He dutifully reported his observations to Murchison whom he recalled 'was rather nonplussed, but thought they were merely local phenomena' (Geikie 1924). Again Murchison had dismissed evidence for Nicol's regional dislocation on the grounds of it being only of local significance. Perhaps Murchison was 'rather nonplussed' because Geikie was reporting that the stratigraphy was inverted and was providing evidence that a 'great line of dislocation' stretched from Eriboll to Kinlochewe (see above); neither supported the Murchisonian hypothesis. Years later Geikie came to realize that his dislocations were a part of

a gigantic system of displacements, by which the whole of the north-west Highlands have been so greatly affected that the very bottom rocks have been thrust up from below, and pushed for miles over some of the younger formations (see Geikie 1924).

That is, Geikie had confirmed, in 1860, the existence of Nicol's grand dislocation but, possibly because of his limited exposure to Highland geology, had allowed himself to be convinced otherwise by Murchison. If Geikie had stuck to his convictions, the Highland Controversy may not have occurred; but then Geikie may not have had his career which would not have been to geology's benefit. No geologist was to publish on the Highland Controversy until after Murchison's death in 1871. Lapworth (1885b) wrote that 'to oppose Murchison was an unpleasant task', especially for academic geologists whom Murchison regarded as amateurs (see Oldroyd 1990; Law \& Johnson 2010).

\section{The re-emergence of the Highland Controversy}

The Highland Controversy re-opened with the paper by Hicks (Hicks 1878) who concluded, largely on mineralogical evidence and the distinctive NW trend of structural elements within the lower (Lewisian) gneisses, that such gneisses were an important component within the eastern gneisses. He also noted that, at Glyn Lagan (Glen Logan), an intrusive rock (syenite) marked the contact between the quartzite-limestone sequence and the typical flaggy eastern gneisses and along which Nicol had placed a fault. Although Hicks was uncertain about the cause of the juxtaposition of the two rock types, he thought the syenite was Lewisian. He concluded that if he was correct, much of the Northern Highlands must be Lewisian. He was more in agreement with Nicol than Murchison.

Huddleston $(1879,1882)$ turned his attention to the distinctive rock that was frequently found along the contact between the quartzite-limestone sequence and the eastern gneiss in the Assynt area. 
He referred to it as the 'Logan rock' because of its abundance at Glen Logan and noted (Huddleston 1882) that "wherever there is "Logan rock" trouble is sure to ensue'. The trouble included the repetition of stratigraphy across it and inversion below it, plus a tendency for the rocks above and below to be 'tortured, intensely folded, dislocated and fragmented'. Huddleston (1879, 1882) also recorded that the Logan rock could have many appearances ranging from a granite or syenite or diorite, to a gneiss, to a mica slate, to a dark green or black aphanitic rock and concluded it was 'an old gneiss partly invaded by extravasated matter' and had been crushed during folding and dislocation. He was the first to directly associate the modification of the texture of a rock to the deformation induced by the movement along the grand dislocation. He (Huddleston 1879) recalled that an outcrop of Logan rock with a thin capping of quartzite 'staggered my faith in the Murchisonian interpretation'. Bonney (1880) examined the Logan rock from Glen Logan both in the field and in thin section. He supported Huddleston's initial observations and concluded that the Logan rock was a gneiss similar to a typical Hebridean (Lewisian) gneiss, but which had been crushed during fault movements.

The Murchisonian hypothesis was further weakened by Callaway who began working in the Highlands in 1880, soon after the first Ordnance Survey maps covering the NW Highlands became available. The six inch Ordnance Survey maps covering the Durness-Eriboll area were published in 1878 (see Fleet \& Withers 2008). The one inch maps with contours followed in 1880 (Cape Wrath) and 1882 (Tongue). It can be seen from his regional map of the Durness area (Callaway 1881), which is reproduced in Oldroyd (1990), that Callaway was using the six inch scale Ordnance Survey maps of Sutherland (sheets 2, 5, 6) as a base. Callaway returned to the Highlands for two weeks in 1881 and two months in 1882 (Callaway 1882, $1883 b$ ). Through progress reports (Callaway 1881, 1882, 1883a) and his main paper (Callaway $1883 b)$, Callaway established that

1. the upper (eastern) gneiss, which he thought was Archaean, had been brought over the 'Ordovician' quartzite-limestone sequence by enormous overthrows resulting from a 'powerful lateral thrust from the east';

2. the quartzite-limestone sequence underlying the eastern gneiss is often folded back on itself, especially in the Eriboll area but less so in the Assynt area;

3 . there is multiple repetition of the quartzitelimestone sequence by folding and faulting, more by the former in Eriboll and by the latter in Assynt;
4. in the area to the north of Ben Arnaboll, the 'quartzite, flags and dolomite occur over and over again and in varied order, as if we had half a dozen successions thrown pell-mell' by 'a confused tangle of faults, folds and overthrows' and was describing the classical imbricate structure of this area;

5. Logan rock is usually Hebridean (Lewisian) gneiss brought/thrust over the quartzlimestone sequence by enormous overthrows, the zone of overthrow can be up to one mile wide as at Loch Glencoul.

Callaway went on to describe the process by which overthrows and overthrusts form during lateral thrusting. He also noted that the 'stupendous inversions and overthrows' that characterize the NW Highlands were similar to those from Alpine areas as shown in the textbook that had recently been written by Geikie (1882).

Bonney (1883) in an appendix to, and during the discussion of, Callaway's paper (Callaway 1883b) noted that in part the Logan rock had the texture of a coarse igneous rock, in part the texture of a gneiss, but always 'bore marks of great crushing' which could result in it appearing as a dark schist when adjacent a fault'. As shall be seen later, these descriptions could equally apply to Lapworth's type locality for a mylonite.

Callaway (1883b) concluded that at Eriboll, 'the evidence for the overthrow or overthrust of the eastern gneiss ... is indeed so distinct that nothing but hastiness of most previous workers can, I think, account for their failure to perceive the true interpretation'. Nicol was the exception and Callaway wrote 'I am glad ... to vindicate his reputation'. During the discussion of Callaway's paper, Hicks noted that no one defended the views of Murchison as then espoused by the Geological Survey.

Fortunately for structural geology, Geikie, who had now become the director of the Geological Survey, had not, at this time, come to appreciate the significance of his observations at Kinlochewe in 1860 (see above section). Convinced that the Murchisonian hypothesis was correct, he sent a Survey team to Eriboll, under the leadership of Peach, to start mapping the NW Highlands. His stated aim was to prove Murchison correct (see Geikie 1884).

Lapworth began mapping the Eriboll area in 1882. He was well aware of the shortcomings of the Murchisonian hypothesis; he regarded Murchison's explanation for the regional metamorphism of the eastern schists as 'impossible and absurd' (Lapworth 1885b). He had, by then, become the bete noir of the Survey because of his papers on the Southern Uplands (Oldroyd 1990). It should be 
remembered that both the six inch and contoured one inch scale Ordnance Survey maps of the Eriboll area had only just become available (see above and McIntyre 1954, quoting Geikie from the annual report of the Geological Survey for 1883) and it was no coincidence that both Lapworth and the Survey team began detailed mapping at about the same time. Lapworth, in the company of Teall, met up with, and spent 'a delightful evening' with Peach and Horne in Durness in 1883 (Teall 1918). The extent to which ideas were exchanged during the course of the 'delightful evening' is not known but some similarities, mainly in terms used, are seen in later papers.

\section{Eriboll mapped and the end of the Highland Controversy}

Callaway (above) had described and illustrated the structural complexity of the Eriboll area. It was Lapworth and, especially, the Survey team under Peach who mapped out that complexity. An example of Lapworth's mapping is seen in Oldroyd (1990). The geological map of the Eriboll area was produced by the Survey team in 1889 . The bulk of Lapworth's work was published in three parts (Lapworth 1883) in which he showed that there was definite repetition within the quartzitelimestone sequence and, more importantly, that elements of it were interleaved with the upper (eastern) gneisses which he termed the Sutherland Series. He thought that both the repetition and interleaving were due to the effects of overthrow folding. His final conclusion was

we have in the so-called metamorphic Silurian of the Highlands of Scotland a portion of an old mountain system, formed of a complex of rock formations of very different ages. These have been crushed and crumpled together by excessive lateral pressure, locally inverted, profoundly dislocated and partially metamorphosed.

He went on to show, using Alpine examples, how this could occur, how overthrow folds could generate overthrow faults and commented on the importance of inward and counter thrusts in the mountain building process. In later papers (Lapworth $1885 a, b$ ) and in his books (Page \& Lapworth 1888; Lapworth 1899), Lapworth brought together overthrow faults and thrusts when he described overthrow faults as moving on thrustplanes. It is interesting to note that Nicol, Callaway and Lapworth had all reached the same conclusion; namely, that the NW Highlands represented the eroded equivalent of a modern mountain belt and did not support Murchison's hypothesis.

The importance of thrusting, as well as folding, in the structuring of the NW Highlands is first seen in the early papers of the Survey team (Peach \& Horne 1884, 1885; Peach et al. 1888) which preceded their classical memoir (Peach et al. 1907). In the first paper, Peach and Horne showed the combined importance of folding and reverse faulting in the structuring of the Eriboll area. For the first time the imbrication of the quartzitelimestone sequence by reverse faults was clearly demonstrated. They also showed that the imbrications were in the footwall of two major gently dipping faults and stated that all were related to a 'peculiar type' of anticlinal fold with a long limb that dipped gently to the SE and a short limb that could dip steeply to the NW or could be vertical or overturned to such an extent that a reverse fault developed and brought the lower beds over higher ones (the overfolds of Nicol, Callaway and Lapworth). Peach and Horne noted that such structures occurred on all scales. They distinguished those that culminated in a grand dislocation, such as Nicol had proposed at Ben Arnaboll, by calling them 'thrustplanes' whereas the minor ones were 'reverse faults'. This distinction often became blurred in their texts (Peach \& Horne 1884; Peach et al. 1888). They also noted that the emplacement of the old (Lewisian) gneiss over the quartzitelimestone sequence at Ben Arnaboll was by a large asymmetric fold (overfold) whose western limb had given way to a major dislocation or thrustplane (now known as the Arnaboll Thrust) along which rocks had been 'pushed for several miles'. The Lewisian gneiss was bound on the underside by an overfolded thrust-plane (Arnaboll Thrust) and bound on the upper by an upper thrust-plane (now known as the Moine Thrust). There had been an extraordinary amount of displacement on the upper thrust-plane independent of that on the lower thrust-plane. That is, the upper thrust-plane was younger and out of sequence. In a diagrammatic section from Durness to Eriboll, Peach \& Horne (1884) showed, in the Ben Arnaboll area, that the upper thrust-plane (Moine Thrust) carried an upper nappe or thrust sheet (Moine) over a lower nappe or thrust sheet (Arnaboll) which had already been emplaced over the quartzite-limestone (CambroOrdovician) sequence by the subsequently folded Arnaboll Thrust. Peach et al. (1888) noted that overfolding became less important and thrust planes more important further to the south and that not all folds culminated in reversed faults.

The work of Peach \& Horne (1884) and Peach et al. $(1888,1907)$ illustrates the value of high quality mapping based on what is seen. Their field data then formed the constraints for interpretation along with a sound geological knowledge supported by laboratory observations, chiefly those of Teall, and experiments, famously those of Cadell which caused them to revise their order of thrust 
propagation (see Peach et al. 1907). Their emphasis was on the factual rather than hypothetical. There is little hypothesizing in the papers of Peach, Horne and co-workers; an exception being their model for metamorphism of the Moine schists (Peach et al. 1888) which was based on the then current hypothesis for mountain development (see below). But unlike Nicol, Callaway and Lapworth who quickly came to the conclusion that the NW Highlands were the ancient equivalent to a modern Alpine mountain belt, Peach and Horne did not do so, in publications, until 1930 (Peach \& Horne 1930). Butler (2010) demonstrates the important role that good geological knowledge and solid theory played in their fieldwork and its interpretation. Murchison and Geikie, on the other hand, appear to have used a preconceived hypothesis to guide their field studies and its subsequent interpretation. The prime example is the importance of the dislocations which both had seen but subsequently overlooked because significant displacements on dislocations did not fit the Murchisonian hypothesis.

The maps of Peach, Horne and co-workers in the NW Highlands are landmark contributions to structural geology; they have been used to formulate and constrain modern models (Elliott \& Johnson 1980) and terminologies (Butler 1982a) in thrust tectonics, and have formed the platform for further studies and mapping along the Moine Thrust Zone (some examples are: McClay \& Coward 1981; Coward \& Kim 1981; Butler 1982a, b, 1987, 2004; Coward 1982, 1983, 1984, 1985; Coward \& Potts 1983; Holdsworth 1989, 1990; Holdsworth et al. 2007) which have added detail but not significantly altered the work of the Survey team led by Peach.

The only controversy created by the early papers of Peach, Horne and co-workers (Peach \& Horne 1884, 1885; Peach et al. 1888) was political rather than scientific. They (Peach \& Horne 1884) made no reference to earlier work. Geikie (1884) in his introduction to Peach and Horne's paper made only a passing reference to Nicol and made it appear that the Survey themselves had proved that Murchison was wrong. This impression was reinforced in his book (Geikie 1885) when he cast Lapworth, Hicks and Callaway, along with Nicol, as causes of the Highland Controversy and stated quite clearly that it was solved by the Geological Survey. These oversights caused furore amongst the academic geologists (Oldroyd 1990). Horne, during the discussion that followed the reading of Peach et al. (1888) 'alluded to the value of Professor Lapworth's work, of which they had the highest appreciation, seeing their conclusions were practically identical'. Geikie (1893) eventually gave equal credit to Lapworth and to the Survey geologists, all of whom were named, for the solution to the Highland Controversy. In his presidential address to the Geological Society on the occasion of the anniversary of its century, Geikie (1908) made only passing reference to the Highland Controversy and made no mention of the Moine Thrust Zone. Perhaps the most fulsome recognition of Lapworth's work is seen in the last publication by Peach \& Horne (1930) who dedicated their book to the memory of Charles Lapworth 'in recognition of his brilliant contributions to Scottish geology'.

In 1885, Lapworth (1885b) published a paper entitled 'On the close of the Highland Controversy' in which he observed that it was 'a period of bitter controversy, of estrangement of Survey men and amateurs, of decline in geological enthusiasm'. He went on to hope that the downfall of the Highland Controversy "marks a new and happier period... when all British geologists shall meet on an equal footing, in mutual communion and sympathy' and that it leads to 'scientific toleration and mutual respect'. I think Lapworth would have been well pleased with the Ullapool meeting.

\section{Thrust and overthrow faults}

The use of the term 'thrust' by the earlier workers is interesting. The earliest mention of 'thrust' in the literature relating to the NW Highlands appears to be by Murchison (1859) when he recorded that the metamorphic rocks at Sango Bay, near Durness, were 'thrust about in dire confusion'. Murchison's 'dire confusion' at Sango Bay relates to a down faulted outlier of the Moine Thrust (see Butler 2007) or a structurally lower thrust (Holdsworth et al. 2006), carrying retrogressed Lewisian gneiss over Cambrian quartzite. Nicol (1860) described the fault, or grand dislocation, that emplaced the Lewisian gneiss over the Cambro-Ordovician sediments at Ben Arnaboll as an 'overthrow fault'. Both Callaway (1883b) and Lapworth (1883) became aware that Nicol's overthrow fault had associated overturned folds which they referred to as 'overthrow folds'. Callaway (1883b) stated, and showed, that the Lewisian at Ben Arnaboll is 'overthrust' over 'Ordovician' sediments by a flat lying reverse fault. He described the process by which this occurred as 'lateral thrusting'. Callaway described and figured a similar situation at Glencoul. Lapworth (1883) illustrated how an overthrow fault could develop from an overthrow fold. As the overturning of the fold tightens and is accentuated, 'instead of the middle limb we now have a surface of dislocation and the arch portion thrusts itself over the trough portion'. Lapworth (1883) went on to describe the process as 'overthrusting' and the dislocation plane as an 'upthrust' plane which was later to became a 'thrust' plane (Lapworth 1885a; Page \& Lapworth 1888). Both Lapworth and 
Callaway indicated that displacements associated with 'overthrusting' could be considerable. Geikie (1884) in his paper introducing the paper by Peach \& Horne (1884) wrote

The most extraordinary dislocations, however, are those to which for distinction we have given the name of Thrust-planes. They are strictly reversed faults with so low a hade that the rocks on their upthrow side have, as it were, pushed horizontally forward.

He neither referred to nor acknowledged the above works of Callaway and Lapworth. In return, his contempories, including Peach and Horne, do not appear to have given any acknowledgement to Geikie for introducing the term 'thrust-plane'. Peach $\&$ Horne (1884) noted that the imbricate system of faults and folds at Eriboll 'culminates in a great dislocation which for convenience of description, and to distinguish from ordinary reversed faults, may be termed a thrust-plane' and is basically what Geikie is describing above. It should not be forgotten that the above paper by Geikie was the result of a short visit he made to Eriboll to check that the field interpretations of Peach and Horne were correct and that Murchison had been wrong. It was made in mid- to late-October, 1884, in atrocious weather (see Geikie 1924). Geikie's paper and that by Peach and Horne which Geikie requested they write whilst in Eriboll (see Geikie 1924) appeared in the journal Nature on 13 November 1884.

By the above reference to 'we', Geikie was supposedly referring to Peach and Horne plus other members of the Survey mapping team. This he clarified (Geikie 1885, 1893) when he credited the origin of the term to the Geological Survey of Scotland. He (Geikie 1885, 1893) wrote that 'thrustplane' was a term used by the Geological Survey of Scotland to describe 'a remarkable type of reversed fault, where the hade is so low that the rocks on the upcast side have been pushed for miles horizontally across the rocks on which they lie'. At this time Geikie was director of the British Geological Survey and was based in London. Perhaps he was indicating that the definition he gave in 1884 was a paraphrase of that being used by Peach, Horne and co-workers.

Peach, Horne and co-workers $(1884,1888)$ used 'thrust-plane' in the above context. But they also used it in the context of sub-horizontal displacements on the vertical shears that affect the Scourie dykes in the Lewisian foreland (Peach et al. 1888). In that sense, they used the term 'thrust-plane' to designate the plane along which movement occurred. However, they also used the term 'thrustplane' for what is now loosely termed a 'thrust'. They went on to name the major thrusts, for example, the Moine Thrust, as the 'Moine Thrustplane'. However towards the end of their 1888 paper, Peach et al. also used the term 'thrust' in the same sense as it is used now, for example, the Moine Thrust-plane became the 'Moine Thrust'.

Lapworth (see Page \& Lapworth 1888; Lapworth 1899) continued to use 'thrust-plane' and regarded it as equivalent to an overthrow fault. Geikie $(1905,1913)$ also continued using the term 'thrust-plane' for a sub-horizontal reverse fault but used the term 'overthrust' if there was associated folding and 'transverse thrust' for a strike slip or transcurrent fault. This usage was continued in his later book (see Geikie et al. 1940, 1953). In their later publications, Peach et al. (1907) and Peach \& Horne (1914) used the term 'thrust-plane' for the plane along which late movement had occurred and 'thrust' for the overall structure. Peach \& Horne (1914) wrote that 'it is often extremely difficult to determine the precise plane of disruption. Owing to the development of mylonitized rocks ... the "thrust-plane" is apt to be lost' and with that distinction they ushered in our modern terminology.

\section{Tectonic regime producing thrust-planes, overthrow faults and overthrow folds}

When considering the early structural studies of the NW Highlands that led to the conclusion (see above) that the thrusts, overthrow faults and overthrow folds indicated the presence of an old eroded mountain belt, we should also consider the then current model for orogenesis. The basis for the model was that mountains were produced through earth contraction due to secular cooling (see Page 1877; Geikie 1882). The development and progressive refinement of the model through the late 19th century into the early 20th century can be followed in the books by Geikie (1882, 1885, 1893, 1903, 1913). A brief outline is included as its refinement came from a better understanding of how structures formed and rocks deformed during mountain building. Orogenesis was viewed as a cyclic process initiated by the slow collapse of the cold rigid crust into underlying space created by the shrinkage and contraction of the cooling nucleus. It was argued that collapse was preferentially sited on pre-existing zones of trans-crustal weakness. By the end of the 19th century Geikie (1893, 1903, 1913) recognized that the interface between oceanic and continental crust was the prominent weakness preferentially exploited during the initiation of orogenesis. The collapsing zones became the sites for the accumulation of thick sedimentary piles, with the base of the pile being progressively heated due to burial metamorphism or pyrometamorphism as it was then known (Page \& Lapworth 1888; Lapworth 1899). Continuation of 
the shortening due to the overall earth contraction first shortened and then led to the extrusion of the infill material out of the collapse structure onto the crustal surface to form mountain belts. Thrusts and the cataclastic deformation of the extruding rocks, along with low temperature regional metamorphism, occurred along the cooler margins of the extruded material as it was forced over either lip of the closing collapse zone onto the cold crust. The result was the formation of the marginal or external zones on either side of a mountain belt such as the Alps. Nappe folds and higher temperature regional metamorphism dominated the hot internal zones of the extrusion where rocks flowed plastically like metals and led to the internal zone of a mountain belt. The plastic and cataclastic deformation and their associated structures graded into each other. The diagrammatic section, drawn by Peach, to illustrate the structure of the entire Highlands conformed to, and illustrates, the above model (Peach \& Horne 1930, fig. 27).

The model could account for seismic and igneous activity that characterized mountain belts. The initial and ongoing collapse led to earthquakes and to deep pressure release igneous activity. Melting could also be produced by the pyrometamorphism of the deeply sinking sediments. These two melting processes were the basis for the explanation of the different categories of igneous rocks identified within mountain belts. Of relevance to the NW Highlands was the explanation for the location of the Moine Thrust Zone and the concentration of thrusts within it. Both resulted from the buttressing provided by the rigid Lewisian foreland (Peach \& Horne 1930, fig. 27). According to Geikie $(1893,1903)$ it caused gigantic pressures to build up and as a result the rocks ruptured into innumerable thrust-planes and faults that were driven over each other. There were fewer thrusts the further one went away from the buttress into the Moine schists. Because of the above model, there was considerable interest in the plastic deformation both of metals and of rocks, perhaps more so than today.

\section{Schists produced at the sheared margins of the Logan rock (sliver of Lewisian gneiss) at Eriboll}

The early workers (see above) noted that the margins of the Logan rock were characterized by the local development of a schistose, fractured, altered and veined rock. Peach \& Horne (1884), and as also reported by Geikie (1884), gave one of the first detailed descriptions on the progressive effects of shearing on the margins of a Logan rock when they described what they observed at the margin of the sliver of Lewisian gneiss that had been thrust over the Cambro-Ordovician quartzites at Eriboll. They recorded that 'a striped green fissile schist' occurred associated with the lower major thrust plane at Eriboll and had a 'remarkable streaked structure' that resembles 'the fluxion lines of an eruptive rock'. Peach \& Horne (1884) noted that the gneiss above the thrust plane 'has a new set of schistose planes superinduced in it which on the whole are parallel with the thrust plane'. They added that fissile schist was produced by 'the enormous mechanical movements' which had induced molecular changes in the crystalline and clastic rocks. The sequence they described resulting from the increasing effects of these 'enormous mechanical movements' was for a more basic component within the Lewisian gneiss. Peach \& Horne (1884) recorded that, as the lower thrust plane is approached from the sliver of Lewisian, the hornblendic gneiss gradated to a hornblende schist, which in turn gradated into a chlorite schist, then into a finely frilled schist and, finally, into a green fissile schist. They recorded that pegmatites following the same gradation ultimately assumed the appearance of a rhyolite.

Peach et al. (1888) noted that from Eriboll to Ullapool 'with each successive maximum thrust there is progressive alteration in the displaced materials as we pass eastwards to the horizon of the micaceous flagstones overlying the Moine Thrust'. They also recorded that with each thrust there is a thin band of slaty schist or sheared gneiss with the foliation being more or less parallel with the thrust plane.

Both Peach \& Horne (1884) and Geikie (1884) recorded that a WNW-ESE-trending lineation, marked by elongate minerals and a preferred direction of crystal growth, had been produced in the above schists by shearing along the thrust-planes. Geikie likened the process producing the schists to 'milling'. There are similarities in the contents of the papers by Peach and Horne and Geikie and again the extent to which Geikie is paraphrasing Peach and Horne is not clear. What is clear is that neither Geikie (1884) nor Peach \& Horne (1884) used the term 'mylonite'.

\section{Defining and describing a mylonite}

In 1883, Lapworth led Teall to Arnaboll Hill. He showed him the sliver of Arnaboll (Lewisian) gneiss (Logan rock) resting almost horizontally on the Cambrian quartzite and explained that the juxtaposition of the two rocks was due to 'an overthrow fault' (Teall 1918). Lapworth invited Teall to sample the foliated rocks along the lower margin of the Lewisian gneiss stating, according to Teall, 'If you want to take a specimen of rolled 
out gneiss take a specimen from there'. Teall recalls that this was the rock which later Lapworth (1885a) called a 'mylonite'. The first definition of the term 'mylonite' was by Lapworth (1885a). Earlier (1883), he had recorded that a 'special type of schistosity', like the slaty cleavage described by Sorby in 1853 , formed a plane of cleavage that marked the dislocations resulting from the shearing out of fold limbs which in turn resulted from overthrusting. In 1884 Lapworth described the rocks along such planes as a type of slate produced by crushing followed by crystallization. He went on to name such rocks mylonites in 1885 .

Lapworth (1885a) defined a mylonite when he wrote

the most intense mechanical metamorphism occurs along the grand dislocation planes where the gneisses and pegmatites resting on those planes are crushed, dragged, and ground out into a finely laminated schist (mylonite) composed of shattered fragments of the original crystals of the rock set in a cement of secondary quartz, the laminations being defined by minute inosculating lines (fluxion lines) of kaolin, or chloritic material and secondary mica.

He added 'mylonites may be described as microscopic pressure breccias with fluxion-structure, in which the interstitial ... paste has only recrystallized in part'. He noted that mylonites were formed along the thrust planes where the two superimposed rock-systems moved over each other as solid masses and that the final appearance of a mylonite depended on the rock types superimposed; a point also made by Peach et al. (1888). Lapworth's basic definition of a mylonite remains adequate (see later section).

In his rewriting of the textbook by Page (Page \& Lapworth 1888) and within his own book (Lapworth 1899), Lapworth further described a mylonite as

\begin{abstract}
The compact platy rock or microscopic shear-breccia typically formed in the numberless overthrow faults (thrust-planes) of mountain regions. It is composed of the flakes and particles of the rocks which have been sheared, dragged, and ground between the jaws of the gliding-planes. The particles are set in a sub-crystalline paste, which is streaked with inosculating veins and fibres of more or less opaque matter. The mylonitic structure and texture is very characteristic of those rocks which have been more or less crushed and sheared in the region of the thrust-planes and thus we have mylonitic gneisses, pegmatites, quartzites etc.
\end{abstract}

The textures of the matrix and of clasts within the matrix were important in distinguishing a mylonite from other rock types formed during movement along the above overthrow faults (thrust-planes). He wrote (Page \& Lapworth 1888)

When the stream-paste is crypto-crystalline or amorphous, and lies in a flowing microscopic tissue of opaque fibres and strings, we have the mylonitic structure [see Fig. 3], named from the characteristic structure of mylonites of Eriboll, which are typically compact, veined, or slaty-looking rocks, so called because they are composed of material ground to a powder, or rock-flour, between the moving masses in the over-faults of that region, like corn between a pair of millstones.

He recognized that clasts could exist in the paste and that these could impart an augen structure or flaser structure (see Fig. 3) depending on the shape of the clasts. He went on to note that the matrix or paste 'flows, as it were, in streams and veins' around the clasts. He added 'When the paste forming these streams is holo-crystalline, the crystals form a mosaic-like ground mass, known as granulitic (see Fig. 3) after the granulites of Saxony'. In his 1888 (Page \& Lapworth 1888) and 1899 (Lapworth 1899) books, Lapworth provided sketches of what he regarded as a mylonitic, a flaser, an augen and a granulitic texture. They are reproduced in Figure 3. He wrote that all four textures could be produced by mechanical metamorphism, that is, by deformation associated with movement along dislocation planes.

Lapworth (1885a) noted that the rocks that developed along the upper thrust-plane marking the transitional contact between the Arnaboll (Lewisian) gneiss and the eastern or Sutherland micaschists (renamed the Moine schists by Peach et al. 1888) at Eriboll were different. These he referred to as 'variegated schists' differing in composition and petrological character depending upon the rock from which they had been derived and what had happened to them subsequently. Their final appearance depended upon the intensity of the many small internal dislocation planes and on the amount of quartz veining developed. The variegated schists could have the appearance of 'frilled schists, veined schists or mica-schists' and were referred to as phyllitic mylonites (Lapworth 1885a). Peach et al. (1888) described these as frilled schists. They are now known as the Oystershell rock or Oystershell phyllonites, after Peach et al. (1907).

The variegated schists passed into the structurally overlying highly flaggy mica-schists which Lapworth noted had the fluxion lines of a mylonite and which he regarded as 'mylonites'. Farther east they could contain mineral grains, mainly feldspar, remaining from the older rock. He named these 'augen schists' and noted that there is every gradation between these and the underlying mylonites. Nowadays, the augen schists are also regarded as mylonites (Evans \& White 1984).

Peach et al. (1888) referred to the slaty schist that occurred along the thrust planes as a 'mylonite' without reference to Lapworth. They referred to the less schistose rock as 'sheared gneiss' but 
(a)

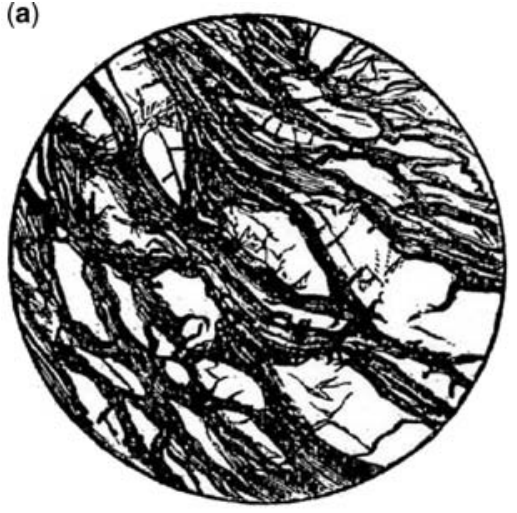

(c)

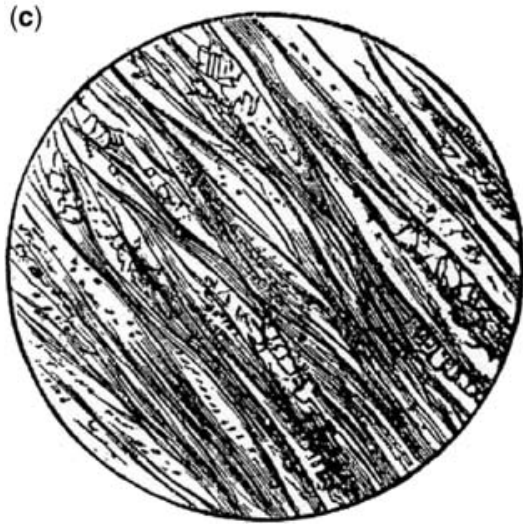

(b)

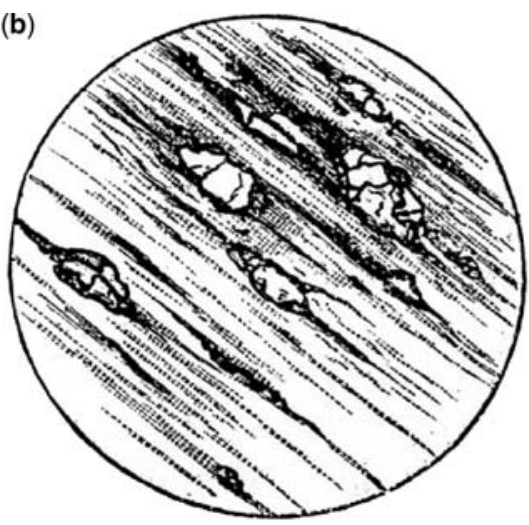

(d)

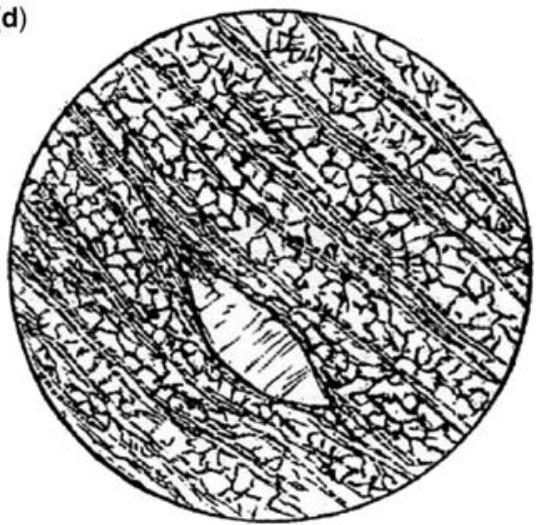

Fig. 3. Textures of schistose rocks as drawn by Lapworth (Page \& Lapworth 1888; Lapworth 1899). He noted that all of these textures could have a mechanical origin and wrote that their cataclastic nature is 'perfectly clear' but added this is less so when the rock becomes holo-crystalline as in the granulite texture. The asymmetric clasts and internal structures displayed in the sketches suggest that all formed as a result of deformation within a shear (dislocation) zone. The term distinguishing each textural type is that used by Lapworth. (a) Macrostructure of a flaser texture. (b) Macrostructure of an augen texture. (c) Microstructure of a mylonite texture. (d) Microstructure of a granulite texture. (Reproduced from Lapworth 1899.)

towards the end of the paper say it too is a mylonite. They used the term 'crush rock' for the more altered slaty schists (mylonites). They also illustrate (Peach et al.1888) how a shear plane parallel foliation progressively developed with increasing shear strain along vertical thrust planes (shear zones), with a sub-horizontal lineation, in the Scourie dykes within the Lewisian foreland to the Moine Thrust Zone. They referred to the resultant fine grained foliated rock as 'crush rock' and the less foliated rock as 'sheared gneiss'. There was initial inconsistency in the manner in which Peach et al. (1888) used the terms 'mylonite, crush rock and sheared gneiss'. Geikie (1885) noted that schistose rocks developed as a result of movement along thrust planes in north-west Scotland with 'the new minerals crystallizing along the shearing-surfaces approximately parallel to the thrust-planes'. In 1893 and 1903, Geikie described 'mylonitic' as a

term introduced to denote the peculiar granular structure of rocks which have undergone intense crushing such as has taken place along lines of fracture and movement such as in faults and thrust-planes. The materials have been reduced to minute grains which have not recrystallized as they have done in the granulitic structure.

He added 'under the influence of continued shearing may develop a streaky arrangement'. In 1903, he added that they had been reduced to a powder and then partially or completely recrystallized. In the above definition, Geikie was at variance with 
Lapworth and Peach and Horne by not regarding a schistose texture as being an essential characteristic of a mylonite. The above reference by Geikie to 'mylonitic' in his textbook indicates that 'mylonite' had entered the general geological vocabulary by 1893 . In 1903, Geikie used 'mylonitic' and 'cataclastic' as synonymous terms.

Teall (1885) had studied shear zones in the Scourie dykes similar to those studied by Peach et al. (1888). Law \& Johnson (2010, fig. 4) show a reproduction of Teall's original sketch of a shear zone in a Scourie dyke. Teall noted that the resultant schistose rocks within the shear zones had been formed by mechanical action but supplemented by complete or nearly complete rearrangement of the minerals to form the schistose rock and differed from those formed mainly by mechanical action (crushing). Teall did not believe that any crushing was involved in the production of these schists; rather they were produced by plastic deformation accompanied by metamorphically induced molecular re-arrangement to form the new minerals. This is, as he points out, at the opposite end of the spectrum from those schists arising from an initial crushing, an observation also made by Lapworth. But unlike Lapworth, Teall $(1885,1918)$ did not make a link between such schists and mylonites. Teall (1885) acknowledged his indebtedness to Lapworth for making him aware of the effects of mechanical action on rocks and adds that Lapworth had not seen the sheared Scourie dykes. In his contributions in Peach et al. (1907) and in his 1918 paper, Teall stated that he did not believe that the schists formed within the Scourie shears were mylonites because they had not undergone crushing. He regarded mylonites as characteristic of zones of fracturing and crushing and the schistose or granular types, as in the above shear zones, being characteristic of zones of flow. This distinction in turn gave rise to the view that mylonite zones were limited to upper crustal levels and passed into the sheared out or attenuated limbs of folds at lower crustal levels (Peach \& Horne 1930, fig. 27). Presumably, in this scenario the mylonites gradated into Teal's schistose or granular rock types at the lower crustal levels but, to my knowledge, this was not stated by Teall or by Peach and Horne. The above figure in Peach \& Horne (1930) is an early representation of the modern model for crustal deformation in which upper crustal deformation is often localized into fault and shear zones and that in the lower crust is more homogeneously distributed.

Apart from the basic distinction between a mylonite and sheared gneiss, neither Lapworth nor Peach and co-workers made any sub-division of mylonites based on the amount of matrix produced to clasts remaining nor did they distinguish between mylonites and cataclasites. These are more modern developments arising from Spry (1969) and followed by Sibson (1977) and will be discussed in a later section of this article. However a forerunner to these is seen in Lapworth's sketches (Page \& Lapworth 1888; Lapworth 1899) of the textural types of rocks related to mylonites (see Fig. 3); the differences are based on the shape and size of clasts and on the amount of matrix. It is interesting to note that Teall (1887) appears to be the first British geologist to use the term 'cataclastic' to describe the above crushing process. It is a term which he took from the publication of Kjerulf (1885) and which was then taken up by the wider geological community, examples being Bonney (1893), Callaway (1893), Lapworth (1899) and Geikie (1903).

\section{Deformation processes producing mylonites}

Peach \& Horne $(1884,1885)$ and Peach et al. (1888) thought that crushing, along with subsequent neomineralization or recrystallization (Geikie 1893, 1903), produced mylonitic type rocks, a process which Teall (1902) likened to trituration. The coarser grained mylonites, such as those produced in the Moine schists or in the shear zones within the Scourie dykes, were thought to reflect greater grain growth after crushing. Geikie $(1893,1903)$ referred to this process as 'granulation' if it resulted in a mylonite with bands consisting of a mosaic of grains. The above authors envisaged that both the grain refinement process and subsequent deformation was by cataclastic processes. Lapworth (1885a), when defining a mylonite (see above), described the deformation producing a mylonite as involving crushing, dragging and grinding of the parent rock. Later Page \& Lapworth (1888) and Lapworth (1899) gave a fuller account of the deformation processes involved. Lapworth wrote, of the deformation that produced mylonites along the great thrust planes, in the following terms 'many of the rocks themselves have been crushed, mashed and dragged out their component sheets, fragments, particles and crystals shearing (or moving over each other with a differential motion, each layer moving a little further than the one below) as the masses gave way, and becoming all finely spread out in new sheets and folia, the planes of schistosity bear a definite relation to the direction in which the general rock mass yielded as a whole' and likened the process to the 'grinding of corn between a pair of millstones'. Lapworth (see Page \& Lapworth 1888; Lapworth 1899) added that on going away from a mylonite, through flaser schists and augen schists, into 

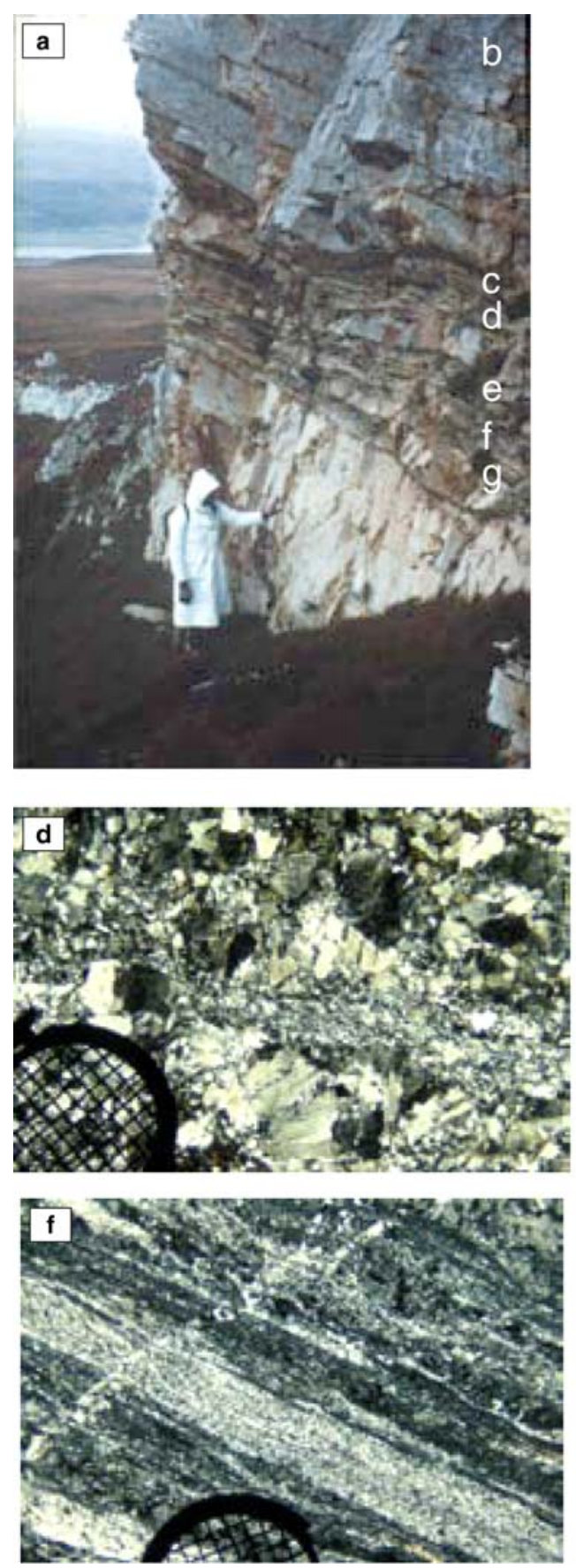
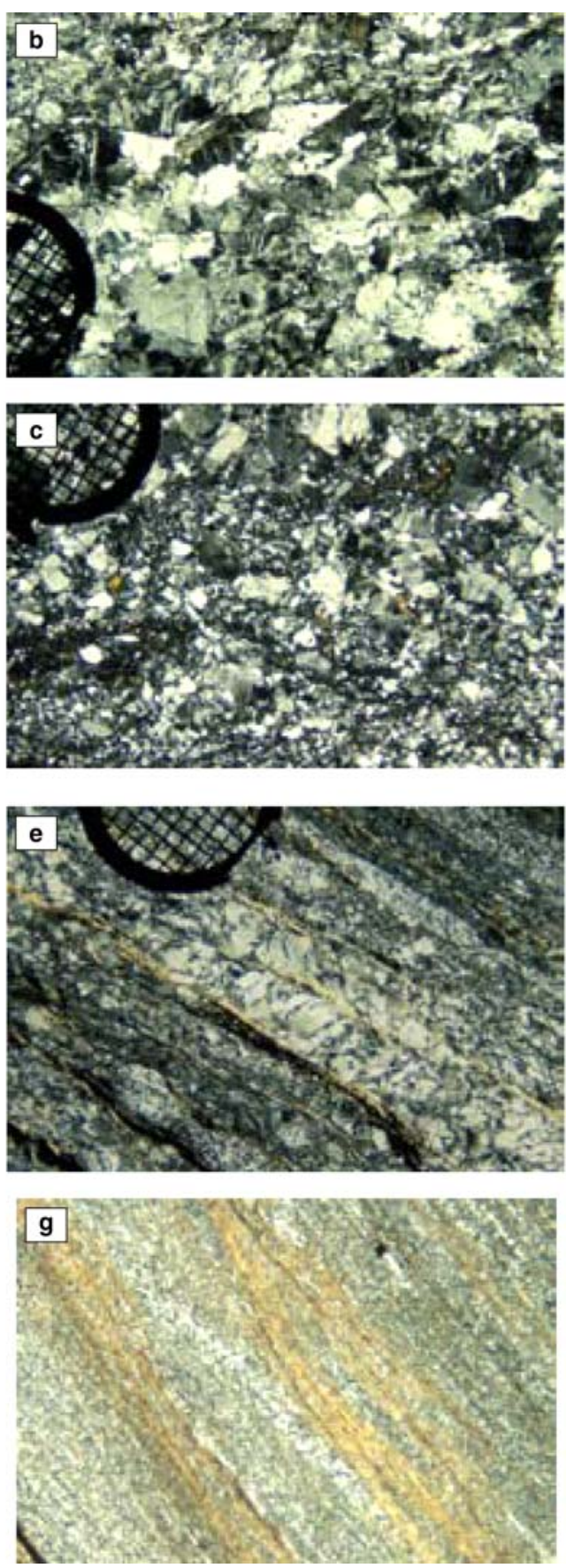

Fig. 4. Lapworth's outcrop and the microstructural sequence from the massive Lewisian gneiss to the well foliated platy mylonite at the base of the Arnaboll Thrust at Ben Arnaboll. (a) The outcrop showing the foliated mylonitic rocks that have developed along the thrust contact between the Lewisian gneiss the underlying Cambro-Ordovician quartzite. (b-g Mark the approximate position of the specimens whose microstructures are shown below). (b) Microstructure of the least deformed, but extensively fractured, massive Lewisian gneiss. (c) The cataclastic microstructure of the massive gneiss in contact with the incipiently foliated gneiss. (d) Microstructure of the incipiently foliated gneiss. The microstructure is basically cataclastic but because of the weak foliation the rock is a mylonite (see text). (e) Microstructure of the upper well foliated rock (mylonite). (f) Microstructure from a well foliated band 
crystalline schists, as seen at Eriboll, the cataclastic component of the texture of the rock becomes less obvious and the rocks pass 'insensibly' into holocrystalline schists. He had previously concluded (Lapworth 1885a) that the augen schists (see above) 'were probably formed in the central parts of the moving system where weight and pressure forced the rock to yield somewhat like a plastic body' and where the differential motion was less. That is, like mylonites, the augen schists were also the products of mechanical metamorphism (see below). Lapworth recognized that both crushing and plastic yielding can produce a mylonite. He was also indicating that the deformation process must 'insensibly' change from cataclasis to plastic yielding as the texture of the rock changes from mylonitic to holocrystalline schistose. Teall (1885, 1918) and within Peach et al. (1907) took the importance of plastic yielding a step further. He concluded that the rocks produced within the shear zones in the Scourie dykes (see above), which we would now regard as mylonitic, had been formed by plastic deformation processes involving two coupled processes, namely deformation induced molecular re-arrangement of component minerals and grain refinement by granulation (recrystallization). He noted that these coupled processes were observed not only in the Scourie dykes but also in the formation of amphibolitic schists elsewhere (see Teall 1885, 1886, 1887, 1918). Later, Read (1931, 1934, 1951) used 'granulation' to describe grain refinement by cataclasis, that is, Teall, Geikie and Read used 'granulation' to describe different aspects of mylonite formation and deformation.

Teall (1918) published a sequence of micrographs from different specimens from different localities to illustrating progressive mylonitization. His specimens included some collected with Lapworth. He recorded that the deformation processes in the mylonites, including those from Ben Arnaboll, could be complex. Quartz and feldspar exhibited different deformation processes. He wrote "plagioclase feldspars often illustrate the cataclastic effects in a very beautiful manner. The first effect is seen in the faulting of the twin lamellae, from this result to the complete breaking up of a large individual into innumerable fragments in a matrix of fined grained mylonitic material every stage may be observed'. He went on to note that under the same deformation conditions quartz responds differently. It

yields more readily to the deforming stresses than feldspar ... it does not as a rule break into separate fragments. It becomes plastic, as it were, losing at the same time its distinctive optical characters and taking on a peculiar kind of crypto-crystalline structure.

Similar microstructural features can be seen in Figure 4 of this article and have been discussed in a previous chapter of this volume (see Law \& Johnson 2010, fig. 3, for a reproduction of Teall's (1918) original photo-micrographs). Teall (1918) went on to add 'that under other conditions ... this distinction between quartz and feldspar is not maintained'. By 'other conditions' Teall was referring to those conditions under which the amphibolite facies shear zones formed in the Scourie dykes. Under these conditions both quartz and feldspar were plastic. Teall (1918 and within Peach et al. 1907) again emphasized that there was no sharp boundary between cataclastic and plastic deformation processes and the manner in which they gradated into each other depended on temperature, pressure and mineralogy.

What did Lapworth and Teall mean by the plastic deformation or plastic yielding of rocks? In other words - what was known about the plastic deformation of rocks and other materials in the late 19th to early 20th centuries? Bonney (1886) and, especially, Mellard Reade (1886) refer to the importance of plastic deformation in the natural deformation of rocks. They and Teall (1885) quote the papers and lectures on the flow of solids by Tresca in the period beginning in 1864 and culminating in his paper published in the Proceedings of the Institute of Mechanical Engineers in 1878 (Tresca 1878). A direct consequence of Tresca's initial papers were early experiments by Miall (1869), who plastically deformed gypsum, and the use of lead by Mellard Reade (1886) as an analogue for the deformation of crystalline metamorphic rocks during mountain building. Millard Reade concluded that crystalline rocks, as seen in modern day mountain belts, were extruded, by solid state flow, from depth by the overlying weight of the mountain belt

Fig. 4. (Continued) within the mylonitic zone. The foliation is marked by alternating quartz-mica rich and fine grained feldspar rich bands. Few feldspar clasts remain. Bulk tensile fractures in filled by quartz veins are common. (g) Microstructure of the platy mylonite in the footwall of the thrust zone, adjacent to the contact with the quartzite. The microstructure is dominated by quartz and mica with lesser albite. Quartz veins infill R-shears. The Lewisian protolith cannot be recognized on the basis of this microstructure. [Scale grid has a diameter of $3 \mathrm{~mm}$; tectonic transport or mechanical movement, as first described by Peach \& Horne (1884) and Peach et al. (1888), is to the WNW and is to the upper left for each photo micrograph. Specimens were cut perpendicular to foliation and parallel to the WNW-ESE trending stretching/mineral lineation, viewing is to the NNE.] 
like lead being extruded from a die during the making of lead pipes. Not all of Mellard Reade's ideas on mountain building were conventional. He appears to have been an early adherent to the expanding earth hypothesis or, at least, an expansion of the cold crust due to heating from below, rather than the contracting earth model (see above). Teall (1885) recorded that Heim had earlier attributed grain elongation in naturally deformed calcite to plastic deformation. It is interesting to note that Kilgour, in the discussion of Teall's (1885) paper, noted similarities in aspects of his (Teall's) paper and the behaviour of metals suggesting that cross fertilization between materials science and geology was occurring at this time. An even earlier example of such cross fertilization in seen in Sorby's early study on the microstructure of iron meteorites (Sorby 1864) and in his seminal work on the microstructures of undeformed, deformed, annealed and recrystallized metals which was presented at the British Association Meeting in 1864 (see Quarrell 1964) and published in two detailed papers in 1886 and 1887 (Sorby 1886, 1887; see also Mehl 1948). Mehl pointed out that the mechanical testing of metals was well established in the 1870 s and that this was also the period during which many British universities inaugurated departments of metallurgical sciences.

In the latter part of the 19th century, two schools of thought had developed regarding crustal deformation. One school, as characterized in the works of Callaway \& Peach and co-workers, saw crustal deformation as being chiefly by cataclastic processes with plastic processes limited to molten or semi- molten intrusive rocks (e.g. banded gneisses) at deeper levels with no gradation from one to the other. The second school, chiefly Lapworth and Teall, saw a complete gradation from cataclastic processes to solid state plastic processes and which was complexly influenced by temperature, strain rate and pressure and better fitted the above model for orogenesis (see pages 513 and 514).

In 1902, Teall made further reference to the importance of plastic deformation and quoted the results of experiments published in 1901 by Adams, a geologist, and Nicolson, a mechanical engineer, in support of his views. Adams \& Nicolson (1901) deformed Carrara marble in the laboratory under variable temperature-pressure-time conditions in the dry and wet state. They found that cataclastic deformation dominated at low temperatures and plastic deformation, by twinning and gliding, occurred at high temperatures $\left(c .400{ }^{\circ} \mathrm{C}\right)$ without cataclasis but with a 'trivial' component of cataclasis at $c .300{ }^{\circ} \mathrm{C}$.

Interestingly, Geikie (1903), who was also aware of the research by Tresca and by Adams and Nichols, changed position from one similar to
Peach and co-workers to one more closely allied to Lapworth and Teall. Initially Geikie (1882) thought that Tresca's research had limited application to geology but came to realize its considerable importance (Geikie 1885, 1893). Finally, Geikie (1903) indicated that, after grain size reduction by cataclasis, a change in deformation process could occur to plastic flow involving molecular re-arrangement accomplished by the shearing of molecules along glide planes. Geikie, by this time, was taking on board the ideas of Teall whom he had earlier persuaded to join the Survey as a petrologist. However, he doubted if crustal deformation was ever entirely free from a component of cataclasis. Geikie (1903) further emphasized similarities between rock and metal deformation when he noted that metals develop the fluxion structure of rocks if deformed to large strains. Sorby (1908) also was aware of such similarities. He noted that the microstructures of deformed metals, especially those that had been rolled at low temperatures, as shown in his papers of 1886 and 1887 , resembled those seen in naturally deformed schists.

In spite of the above comparisons between rock and metal deformation, cataclastic processes with associated mass transfer, chiefly pressure solution (Sorby 1853, 1856, 1879), remained the most quoted mechanism for crustal deformation until the mid-20th century when Griggs and co-workers succeeded in inducing plastic flow in silicates (see Passchier \& Trouw 2005 for references). Even the granulation (recrystallization) process of Teall was viewed as the result of grain growth after grain refinement by cataclasis (Read 1931, 1934, 1951; Read \& Watson 1962). There were exceptions. One example is Geikie (see Geikie et al. 1940, 1953) who foresaw the importance of pressure as well as temperature. He wrote that plastic flow would be favoured by high pressures (as experienced in the internal zone of a mountain belt where shortening was dominated by folding, see above and Peach \& Horne 1930, fig. 27) and cataclastic flow by lower pressures (as in the external zone where shortening was dominantly thrusting) and could pass one into the other by 'insensible gradations'. The above figure in Peach \& Horne (1930) is an excellent illustration for what Geikie wrote, showing the thrusts of the external zones passing into folds at depth and being replaced by folds in the internal zone. It would appear that Peach \& Horne (1930) shared Geikie's view on the change in deformation mechanisms. Another example is Balk (1952) who explained quartz $c$-axis fabrics in his mylonites as being produced by a deformation akin to the rolling of a metal.

A further question with respect to deformation related to mylonites, and related rocks at Eriboll, 
arises from the following statement by Lapworth. In 1885, he (Lapworth, 1885a) wrote that the

present physical relationships ... between the Arnaboll gneiss, the variegated schists, the augen schists and the Sutherland (Moine) schists ... are the effect of lateral crust creep by which ... they ... have been forced over the Palaeozoic rocks in grand overfaults to the west often for many miles.

What did he mean by 'crustal creep'? In 1899 , Lapworth indicated that it was the response of the earth's crust to lateral pressure that can result in mountain chains and in regional dynamometamorphism. He (Lapworth 1899) went on to note that "the Mechanical action of Lateral pressure (or crust-creep) alters the rock subjected to its influence both structurally and texturally' and added that the thrusts of NW Scotland were produced by crust-creep. Geikie (1913) also used the term 'creep' in reference to mountain development. He wrote that crustal creep was a process involved in the development of the Alps and that great rock masses would 'creep along approximately horizontal thrust planes' during Alpine development. The views expressed by Lapworth and Geikie are similar to modern-day views. They raise the question - what was known about creep deformation in the late 19th and early 20th centuries?

By the late 19th century, creep deformation of metals had been established (see Muir 1899) following earlier studies (see Ewing 1880). Microstructural studies of deformed metals were also well established by this time (see Ewing \& Rosenhain 1899, 1901) following introductory metallographic research by Sorby (1864) as indicated above. The classical creep studies of Andrade were published in 1910 and 1914. It is not certain what Lapworth and Geikie exactly meant by crustal creep. However, the way in which Lapworth used the term 'plastic yielding' and he and Geikie used the term 'creep' indicates that both were aware of then current literature on metal deformation which, in Britain, was mainly published within the journals of The Royal Society.

Finally, in what sense was Lapworth using the term 'rolled out gneiss' when introducing Teall to his mylonite locality at Ben Arnaboll in 1883. The analogy that crystalline schists, gneisses and mylonites appeared, from their texture, to have been produced by the natural equivalent to the rolling or extruding of metals is prevalent in geological publications in the middle to late 19th century (see above) and continues to be prevalent in more modern times. Balk (1952) noted the similarity between the microstructures of rolled metals and mylonites. White $(1979 c)$ and White et al. (1980) also stressed that there were similarities not only between the microstructures of metals, especially steel which had been rolled at low temperatures, and mylonites, but also in the internal structures (foliations) in both. They used the metallurgical term 'shear bands' to describe the oblique, partially penetrative, intrafolial, internal shears often seen in mylonites, such as those at Eriboll and especially in the variegated schists, because they were geometrically similar to features common in cold and warm rolled steel.

Perhaps the final word on the deformation processes that produce a mylonite lies with Teall. In 1885, he posed 'three important questions' related to the genesis of shear zone or fault zone related rocks that then remained to be solved. They were as follows.

a) Under what conditions is the deformation accompanied by a crushing of the individual constituents?

b) Under what conditions is it accompanied by entire molecular rearrangement (plastic flow and recrystallization)?

c) Under what conditions do these two more or less opposites occur at the same time?

As will be seen later, these three questions still remain with us to varying degrees.

\section{The lineation associated with the mylonites along the Moine Thrust Zone, especially at Eriboll, and its kinematic significance}

Lapworth (1885a) makes little mention of the prominent lineation seen in the mylonites and schists associated with his grand dislocation, although Callaway (1883b) had recorded slickensides within the Logan rock. On the other hand, Peach \& Horne $(1884,1885)$ and Peach et al. (1888) treated it in some detail. They noted, in their 1884 paper, that the schists along the thrust planes at Eriboll had a streaked appearance due to "their component particles of quartz and feldspar being all elongated in one common direction'; they were describing a stretching lineation. They added that the streaked minerals, which could include mica, could also form fine parallel lines, like slickensides, on the foliation planes and quartz veins could be drawn into parallel rods (see also Wilson 1953). The observed lineation always had the same general trend, namely WNW-ESE. Peach \& Horne $(1884,1885)$ wrote that the lineation was the result of the 'enormous mechanical movements under which the individual particles were forced over one another in one common direction, from ESE to WNW'. Geikie (1884) also noted the same features about the lineation, but in his later books (Geikie 1885, 1888, 1893, 1903) made no mention of the kinematic significance of the lineation. Peach et al. (1888) confirmed that the lineation 
occurred over the length of the Moine Thrust Zone, had a common direction and indicated a regional tectonic transport from 20 to $40^{\circ}$ south of east. Later workers would periodically reconfirm that the stretching lineation is remarkably consistent not only throughout the Eriboll area (Wilson 1953; Soper \& Wilkinson 1975; McClay \& Coward 1981; Butler 1982b; Evans \& White 1984; Bretan 1985; Holdsworth 1989; Holdsworth et al. 2007) but over the whole of the Moine Thrust Zone (Philips 1937; Anderson 1948; McIntyre 1954; Johnson 1957; Christie 1960; Barber 1965; Law et al. 1984, 1986; Coward 1985; Allison et al. 1988; Law \& Johnson 2010, fig. 5).

Peach \& Horne (1884) and Peach et al. (1888) demonstrated the kinematic significance of the above stretching lineation by its geometric relationship to regional and local thrust geometries. They supported this by the oldest known use of kinematic indicators that had formed in mylonites, namely asymmetric clast shapes, rotation of markers such as the pipes in the Pipe Rock or external foliations, geometry of intrafolial folds and oblique foliations (what we would now term s-c and $c-c^{\prime}$ or shear band fabrics) to conclude that the lineation tracked movement (tectonic transport) within the mylonites from the ESE to the WNW. However, this would be disputed (see details in Law \& Johnson 2010). Philips $(1937,1945)$ argued, mainly on petrofabric evidence, that the regional lineation in the Moine schists, including the mylonitized Moine schists (Philips 1937), was not a stretching lineation but a b-lineation of the type described by Sander (see references in Philips 1937; Law \& Johnson 2010). Consequently Philips $(1937,1945)$ concluded that the lineation was parallel to fold axes (see below) and is therefore perpendicular to the direction of tectonic transport. Although this view was opposed by Anderson (1948), it continued to find favour (Wilson 1953; McIntyre 1954; Christie 1960); see also historical reviews by Howarth \& Leake (2002) and Law \& Johnson (2010). The opposing interpretations were reconciled by proposing that the deformation producing the lineation in the Moine schists, on the one hand, and in mylonites, on the other hand, were two distinct events with the b-lineation in the Moine schists produced earlier than the thrusting; see discussion of the paper by Wilson (1953), review by McIntyre (1954) and paper by Christie (1960). In this scenario, the thrust event was thought to be Caledonian and the production of the b-lineation to be preCaledonian. Horne had similar views whereas Peach held the view that the metamorphism, folding and thrusting represented a single post Cambrian event (see McIntyre 1954).

Christie $(1956,1960)$, in his study of the mylonites associated with the Moine Thrust at the
Stack of Glencoul, proposed that the lineation within the mylonites was also a b-lineation and indicated that kinematic transport within the Moine Thrust Zone was in a NNE-SSW direction. There ensued a controversy over the direction of transport along the Moine Thrust Zone, chiefly between Christie (1960, 1963, 1965) and Johnson (1957, $1965,1967)$ who regarded the lineation as a stretching lineation indicating WNW-directed transport. The controversy was eventually hammered out in favour of Johnson and indirectly in favour of Peach and co-workers, Lapworth, Callaway and Nicol. It is now generally accepted that both the deformation and metamorphism associated with the thrusting and within the Moine schists represent phases of a Caledonian event in which transport was to the WNW (Johnson et al. 1985; Holdsworth et al. 2007); see historical and regional reviews by Howarth \& Leake (2002), Strachan et al. (2002) and Law \& Johnson (2010).

Enigmatic observations, however, remain. Two of these are listed below. Firstly, en echelon quartz tension gashes in incipient shear zones in the Moine schists at Melness (see Fig. 2 for location) indicate a north to south movement in the footwall to the Ben Hope Slide (Wilson 1952). Secondly, garnets in foliated amphibolites in the hanging wall of the Ben Hope Zone (Slide or Thrust), in the same area, were rolled with the WNW-ESE lineation as the axis of rolling and indicating a SSW-NNE line of transport (McLachlan 1953).

\section{Metamorphism producing mylonites}

Lapworth (1885a) used the term "mechanical metamorphism' to describe the metamorphic process that produced a mylonite. He wrote that the original crystals within the Arnaboll gneiss 'are crushed and spread out and new secondary minerals are developed. The most intense mechanical metamorphism develops along the grand dislocation planes' (Lapworth 1885a). Peach et al. (1888) also concluded the metamorphism that produced the flaggy schists (mylonites) along the thrust planes of the Moine Thrust Zone was by a metamorphic process similar to that described by Lapworth. However they thought that the mechanical metamorphism was an integral part of regional metamorphism and which is due to the dynamical and chemical effects of mechanical movement acting alike on crystalline and clastic rocks'.

Bonney (1886) in his presidential address to The Geological Society indicated that the basic distinctions between contact and regional metamorphism were well understood in the latter half of the 19th century. He recognized a third type of metamorphism resulting from 'great earth movements' and which he distinguished from regional 
metamorphism by referring to it as 'pressure metamorphism'. Teall (1886) also used pressure metamorphism to describe the metamorphism associated with the affects of mechanical energy due to shearing and used a deformed gabbro with a classic mylonitic texture as an example. Later Teall (1902), in his presidential address to The Society, recalls that Lossen in 1867 had described a similar metamorphic process as a 'dislocation metamorphism' and which indicated its direct association with a fault. Teall (1918) went on to use the term 'dynamic metamorphism' to describe the metamorphic conditions that produced mylonites. In finally arriving at this term from his original use of 'pressure metamorphism', he used the terms 'dynamic metamorphism' (Teall 1887, 1888), 'dynamo-metamorphism' (Teall 1902, see also Callaway 1893) and 'thermodynamic metamorphism' (Teall 1902) as he wrestled with the relative roles and scales of the mechanical and thermal effects. In his 1902 paper, he listed slates as examples of dynamo- or thermodynamic metamorphism. In 1918, Teall included slates as an example of dynamic metamorphism as one of two end members, namely localized dynamic metamorphism producing mylonites and schists in shear zones and regional dynamic metamorphism producing slates and schists over large areas (e.g. the schists of NW Scotland). Lapworth (1899) also grappled with the type of metamorphism that produced slates and, like Teall (1918), considered that both mylonites and slates formed during 'dynamo-metamorphism'. In such a scheme, mylonites formed when it was localized (equivalent to the mechanical metamorphism of Peach and Horne and Lapworth, see above) and slates when it was more regional. In this context, mechanical metamorphism would be a sub-division of dynamometamorphism which, in turn, along with pyrometamorphism (equivalent to burial metamorphism) were sub-divisions of regional metamorphism. However, for reasons that are not clear, Lapworth made no mention of mechanical metamorphism in his later books (Page \& Lapworth 1888; Lapworth 1899), nor did Peach et al. in their 1907 memoir. Perhaps they had foreseen the problem later highlighted by Read (discussed below).

Lapworth and Teall appear to have only used the term 'regional metamorphism' to indicate the areal extent of metamorphism irrespective of the contributing metamorphic processes. Geikie (1882), on the other hand, sub-divided metamorphism into regional and contact types. As a result of the closing of the Highland Controversy, he came to regard mechanical deformation as an essential component of regional metamorphism (Geikie 1885). The schistose rocks of the type to be named 'mylonites' by Lapworth in the same year formed during regional metamorphism in those areas where mechanical deformation was most intense, namely, where rock masses sheared over one another along thrustplanes (dislocations). Later Geikie (1893, 1903) saw the need to distinguish between the metamorphism producing mylonites and slates from schists and from each other. Besides 'normal' regional metamorphism, he introduced two sub-classes, namely dynamo-metamorphism producing mylonites and dynamothermal metamorphism producing slates. This distinction was continued in later editions of his books (see Geikie et al. 1940, 1953).

At the start of the 20th century the terminology associated with regional metamorphism and the place of mylonites in such a scheme had become subjective and confused. But so far as the Moine Thrust and the Moine schists were concerned, the notion was that the metamorphism in the Moines progressed from mylonite or cataclasite to schist and gneiss (chiefly Peach \& Horne, Lapworth, Geikie). Perhaps this reflected their initial attention to the Cambro-Ordovician sediments at Eriboll which went from sediment to schistose mylonite as the major thrust-planes (dislocations) were approached and likewise for the massive Lewisian at Ben Arnaboll. They extended this logic to the Moine schists. Read (1931, 1934) who worked from the Moine schists into the Moine Thrust Zone, took exception to this notion, somewhat strongly, and argued that the progression was the other way, namely from schist or gneiss to mylonite or cataclasite. Read (1934) stressed that the Moine schist, and Lewisian gneiss within it, were being retrograded into the mylonite zones associated with the thrust-planes, whereas Lapworth, Peach and Horne and Geikie were effectively indicating that the dislocation or thrust-plane related metamorphism was prograde. Perhaps to counter the notion that mechanical metamorphism had produced the schistosity in the Moines as it had done in the Cambro-Ordovician sediments, Read (1934) re-introduced the term 'dislocation metamorphism' to distinguish and disconnect the retrograde nature of most of the mylonite zones in the Moine schists from the regional or general metamorphism that produced the Moine schists. Read had concluded that the dislocation metamorphism was later than the regional metamorphism of the Moine schists (Read 1934). Peach and Horne, Lapworth and Geikie thought they were co-eval, although, as stated above, Horne later came to an opinion similar to Read (see Law \& Johnson 2010). Read \& Watson (1962) defined dislocation metamorphism as being confined to changes taking place in restricted belts of concentrated earth movement such as along thrusts or shear zones in regions where no other kind of metamorphism was in progress. They emphasized that 
dislocation metamorphism was essentially retrograde. Christie (1960) used Lapworth's term 'mechanical metamorphism'. Spry (1969) reverted to 'dynamic metamorphism' which remains in current use. Spry also included slates as an example of dynamic metamorphism and in doing this was following Teall's $(1902,1918)$ example. Confusingly, Spry's classification scheme for dynamically metamorphosed rocks only included rocks formed within shear or fault zones, chiefly mylonites and cataclasites; he appears to have solved the problem of what to do with slates by overlooking them in his classification. This has resulted in the term 'dynamic metamorphism' being limited to shear zone or fault zone related rocks. The current recommendation of the IUGS (Smulikowski et al. 2007 ) is that the term 'dislocation metamorphism' be used. Currently a dislocation is no longer used in the geological literature to indicate a fault or shear zone, we now use it in its materials science context. It is interesting to note that Read (1934) returned to the term 'dislocation metamorphism' at exactly the time when materials scientists were appropriating the geological term 'dislocation' to describe a linear lattice defect that allowed crystals to shear easily along slip planes (Taylor $1934 a-d$ ). It would be more appropriate to use the term 'shear and fault zone related metamorphism' to describe the process that produces mylonites and cataclasites which, as will be discussed later, are classified as shear and fault zone related rocks.

\section{Lapworth's textural sequence from gneiss to mylonite}

Lapworth's outcrop at Ben Arnaboll (see Fig. 2 for location), which Teall sampled, is well known from Teall's description and is shown in Figure 4a. Lapworth (1885a) wrote that the Arnaboll gneiss can be traced from spots where it retains its original texture and petrology to where these are obliterated and new ones developed. Teall (1918) published a series of photomicrographs (see also Law \& Johnson 2010), some selected from specimens he collected in the company of Lapworth in 1883, and which illustrate the progressive development of a mylonite from the undeformed Arnaboll (Lewisian) gneiss. A similar sequence, consisting only of samples from Lapworth's locality at Ben Arnaboll, is shown in Figure 4b-g. Lapworth (Page \& Lapworth 1888; Lapworth 1899) included a sketch of the microstructure of a mylonite in his textbooks but did not indicate from where the specimen came, presumably it was from Ben Arnaboll.

The massive Lewisian gneiss exhibits a typical gneissic microstructure (Fig. 4b) consisting of coarse plagioclase, orthoclase feldspar and subsidiary quartz. The microstructure shows extensive fracturing. The fractures, which are usually infilled with quartz, locally displace grains but do not alter the gneissic microstructure. The quartz grains have strongly developed internal optical strain features, mainly deformation bands and elongate sub-grains with small equidimensional sub-grains forming in grain mantles and passing into recrystallized grains at the grain boundary. The feldspar grains show evidence for intragranular plasticity, mainly deformation twins, bent twin lamellae and banded undulatory extinction. Grain refinement is by fragmentation (see also Teall 1918). As the foliated zone is approached, there is extensive cataclasis producing a marked grain-size reduction and a fine grained matrix, the cement or paste of Lapworth (Fig. 4c). There is no perceptible foliation and parentage is obvious. The rock produced is a proto-cataclasite. The most noticeable mineralogical change at this stage is the appearance of epidote, a feature commonly commented upon by those who studied the Logan rock in the 19th century (see above). An incipient, initial foliation (Fig. 4d) is produced by segregated bands of quartz and mica with individual quartz grains elongated oblique to the trace of the bands to form an s-c fabric (see Passchier \& Trouw 2005). Feldspar clasts have been extensively fractured and fragmented. Fractures, in a tensile orientation during shear induced flow, are pulled apart and in-filled with fibrous quartz grains. The fibres are orientated parallel to the elongation of the grains forming the $\mathrm{s}-\mathrm{c}$ fabric. The main difference between the microstructure in Figures $4 \mathrm{c}$ and $\mathrm{d}$ is the advent of a weak foliation; the deformation is predominantly cataclastic in both. In the descriptive classification of Spry (1969) and Sibson (1977) the rock has changed from a protocataclasite to a protomylonite. The mylonite stage (Fig. 4e) is marked by the first appearance of a well foliated rock. There has been a marked increase in the abundance of quartz and mica with a schistosity defined by mica rich planes and by bands with differing mineralogy and grain-size. Rounded and ellipsoidal feldspar augen develop in the fine grained bands where it appears that grain refinement is now also occurring by the chemical and strain induced recrystallization to metamorphically stable albite. Angular fragments of plagioclase dominate the feldspar rich bands with grain refinement dominantly by cataclasis.

The increased definition of the foliation in hand specimen is accompanied by a better defined banding due to the marked segregation between the streaked out fine grained feldspars and quartzmica bands (Fig. 4f). The reworking and grain size diminution of the feldspars is achieved largely by cataclasis and then by neomineralization and recrystallization as the feldspars chemically readjust 
to the ongoing metamorphic conditions in the finer grained bands where the ingress of water has focused. The final result of these combined processes is to produce a mylonitic rock in which the protolith feldspars have been almost totally reworked and the microstructure consists of alternating quartz-mica and albite-quartz-mica bands. Quartz veining is present. Further re-working of the feldspar rich bands produces an intensely foliated rock (Fig. 4g); the green fissile schist of Peach \& Horne (1884) or slaty schist of Peach et al. (1888). The darker bands in Figure $4 \mathrm{~g}$ are the remnants of the feldspar rich bands in Figure 4f. It is no longer possible to recognize that the protolith to the microstructure seen in Figure $4 \mathrm{~g}$ was a Lewisian gneiss; it could just as easily have been a Moine schist or a quartz rich rock from the Cambro-Ordovician sequence. This is a point made by Peach \& Horne (1884), namely, the same slaty schist is produced along the contact where rocks have been juxtaposed across a thrust plane, irrespective of the protolith. The slaty schist is an ultramylonite in Spry's (1969) and in Sibson's (1977) terminology or a mylonite to Lapworth (1885a) and Teall (1918).

Quartz veining is still present in the ultramylonite. Quartz veins have infilled R-shears which have then back-rotated indicating that they remained as active R-shears after their initial infilling by quartz. Quartz veins which infilled fractures perpendicular to the foliation remained essentially as passive markers during subsequent deformation and were folded or forward-rotated.

It is interesting to note that the first record of the description of a thin section from Lapworth's locality is by Bonney (1886) for a specimen lent to him by Teall from the collection he made with Lapworth. Bonney noted that it had a microstructure remarkably similar to that of a Logan rock from Glen Logan and also had 'quartz granules having a peculiar dragged-out, clotted aspect, and having their optic axes approximately parallel, so as to produce a marked uniformity of tint when examined with two Nicol's prisms'. This may be the first description of a preferred crystallographic orientation produced during the deformation processes resulting in a mylonite.

Transmission electron microscopy (TEM) observations on the above rocks have been reported in a brief study by White (1998). Quartz grains in the cataclased gneiss and clasts in the mylonites display similar structures, namely sub-grains with walls defined by picket fences of dislocations with low densities of dislocations within the sub-grain interiors. Grain refinement is by recrystallization. Within the phyllosilicate free quartz bands in the mylonite, the quartz has a coarser grain-size (510 micron) than the quartz in phyllosilicate rich bands ( 5 microns or less). The latter sub-grain size is similar to the sub-grains in the quartz clasts within the mylonites suggesting sub-grain rotation as a nucleating process for the recrystallized grains. It is the multiple diffraction effects due the small grain size of the quartz that produced the cryptocrystallinity referred to by Teall (1918). In the ultramylonite, the size ( $<5$ micron) and shape of the quartz grains are controlled by intercrystalline phyllosilicates. The alkali feldspar and plagioclase grains in the cataclased gneiss and within clasts in the mylonite exhibit narrow (typically $<1$ micron) and often closely spaced (c. 5 micron) deformation twins. The areas between the twins are highly dislocated consisting of small $(<5$ micron) subgrains with high internal densities of tangled dislocations. Grain refinement on the coarser scale is by cataclasis but on the finer scale is by the chemically and strain driven nucleation of strain free albite grains.

The ultra-fine grained bands that form the interstitial paste defining the fluxion lines of Lapworth consist of ultra-fine ( $<5$ micron) grained quartz, with some albite grains of a similar size. Small white mica and chlorite grains, often less than 1 micron, occur both along the grain boundaries and within the quartz grains. Dislocations occur within the quartz grains. The darker fluxion lines also contain fine grained epidote and iron oxides. The electron microscopy shows that Lapworth's subcrystalline or amorphous paste always consists of crystalline material albeit with a grain size below the limit of resolution in an optical microscope, especially when using a standard 30 micron thinsection. The TEM studies of these and of other mylonites from the Moine Thrust Zone (Weathers et al. 1979; White 1979a, b; Ord \& Christie 1984; Knipe 1990) have not produced evidence to suggest that the coarser grained mylonites were originally the ultra-fine grained paste that underwent later grain growth as thought by Peach et al. (1888).

\section{Deformation processes producing the mylonites in Lapworth's type section}

As stated above, there is a current tendency to regard a mylonite as the product of ductile flow due to dominant crystal plastic processes (Passchier \& Trouw 2005). Essentially, however, a mylonite is the product of a large strain deformation within shear zones irrespective of the deformation process (see above). The mylonites produced at Ben Arnaboll underwent initial deformation and grain refinement by cataclasis, that is, by crushing in the terms of Lapworth (1885a) and of Peach et al. $(1884,1885,1888)$. The deformation then changed to dominant crystal plastic processes, 
with subsequent grain refinement by recrystallization, as the mineralogy changed to a mechanically weak mineral assemblage, namely fine grained quartz and mica. Cataclasis remained important with respect to the feldspar clasts and fracturing remained a contributing process in the bulk deformation. As Lapworth, Teall and Geikie had concluded, there is no sharp transition from cataclastic to (crystal) plastic deformation processes in mylonitization (see above section). They are two end member processes which imperceptibly transit from one to the other depending on rock type, mineralogy and deformation conditions.

The tendency for the above bulk fractures, which are often oblique to the foliation, to follow an R-shear orientation indicates that ductile fracturing (Smallman 1985), involving void development and coalescence, had contributed to development of the mylonites. The change from brittle to ductile fracturing is an expected part the imperceptible transition from cataclastic to crystal plastic deformation. Furthermore, we should not overlook the comment by Huddleston (1879) that extra material, including water, is being added to the mylonitic mill throughout the milling process and will affect the deformation behaviour of the rock in the mill in a manner dependent upon what is being added and when it is added (see White \& Knipe 1978; White et al. 1980).

Both Lapworth and Teall, recognized that crystal plastic process could also produce a mylonite, or mylonitic type rock, depending on deformation conditions, for example, strain rate, temperature, pressure and mineralogy (see above). That is, a mylonite is not the product of a specific deformation process or mechanism. If we only studied Figure $4 \mathrm{~g}$, we would have no knowledge of the deformation processes or mechanisms that produced it from the microstructure of Figure 4b. We would know only the mechanism operating after the microstructure in Figure $4 \mathrm{~g}$ had been produced. If we do not know the deformation processes and mechanisms, we cannot ascribe a flow law. That is, what type of flow law should we use to describe the production of an ultramylonite from the Arnaboll gneiss? This in turn questions the relevance of simple creep equations when we come to model the rheology of a mylonite zone.

A further problem arises when the progressive grain size reduction with shear strain is considered. White (1979a) used both grain size and sub-grain size of quartz deformed by crystal plastic processes to estimate paleo-stresses associated with the development of a quartz mylonite in a centimetric scale shear zone within the imbricate zone at Eriboll. He found up to an order of magnitude increase (c. $30 \mathrm{MPa}$ to $c .300 \mathrm{MPa}$ ) from edge to centre of the shear. Across the mylonites associated with the Moine Thrust, the stress intensification is from c. 30 to $c .180 \mathrm{MPa}$ (White $1979 b$ ). The question is how can such a stress gradient be maintained over a period of time? It makes better sense if the grain and sub-grain size gradients reflect a strain rate gradient. This in turn points to a warm or hot working type of deformation process, as occurs in the rolling of metals, rather than a creep process. If true, this has implications for how we model not only mid- to deep crustal rheology but also that of the upper mantle.

\section{Deformation processes producing unfoliated fault rocks (cataclasites) in the Eriboll area}

Microstructural studies of the unfoliated cataclastic rocks within the Moine Thrust Zone are rare. An exception is the study by Moore (1980) of cataclasites from the Conamheall area at the southern end of Loch Eriboll. Her findings are summarized below.

The cataclasites occur along thrusts forming an imbricate structure associated with the Sole Thrust and which cause duplication of the CambroOrdovician sediments. The thrusts were marked by zones, up to $5 \mathrm{~m}$ thick, of cohesive fragmented Pipe Rock. The fragments sit in a matrix of whitish flinty material near the edges of the zones and gradate into black flinty material, which also formed narrow centimetric bands of more intense cataclasis, in the centre of the zones.

Samples were taken from the Pipe Rock adjacent to the zones and from clasts within the zones. They were also taken from the white and black flinty matrix and from the black flinty bands of intense cataclasis. Optically, the quartz grains from samples adjacent the zones showed no elongation but did exhibit undulatory extinction and may contain deformation bands. The intensity of both features increased in the quartz grains within fragments in the cataclasite. Small equidimensional quartz grains were visible in the whitish matrix and appeared to be recrystallized grains in the process of coarsening. Very little detail can be resolved in the black flinty matrix or in the black flinty bands.

Transmission electron microscopy showed narrow elongate sub-grains with typical picket fence type dislocation walls and with a high density of internal dislocations in quartz grains from Pipe Rock adjacent to the thrust zones. These were replaced by a sub-cell structure made of diffuse walls consisting of hedges of tangled dislocations and with very high internal densities of dislocations. The white flinty matrix consisted of small (1-5 micron) recrystallized quartz grains which may contain internal dislocations. Although no direct evidence was seen, these grains may have nucleated from the sub-cells. The black flinty 
matrix and especially the black flinty material in the bands consisted of very small (typically $<1$ micron) irregularly shaped quartz grains which appear to be growing into each other. Their microstructure resembles the pressure solution welded microstructure produced during experiments on quartz rich gouges that have been re-deformed at temperature (Rutter \& White 1979). Within this microstructure were grains that have a sub-euhedral outline and were starting to assume the appearance of a recrystallized grain although grain refinement has been by comminution.

Moore's observations indicate that crystal plastic deformation mechanisms, akin to warm working which produce sub-grains or cold working which produce the sub-cells, can contribute to the development of a cataclasite. Her observations also indicate that when grain refinement occurs by cataclasis, subsequent mass transfer by pressure solution can lead to a microstructure similar to that produced by recrystallization. The distinction would lie in the crystallographic fabric. The quartz grains produced by the former process should have no marked crystallographic fabric. But, nor may quartz grains produced as the result of grain refinement by recrystallization if it induces subsequent deformation by grain boundary sliding mechanisms.

\section{Differentiating mylonites from schists or where do the Moine mylonites end and the Moine schists start?}

A cause for the failure by Murchison and, to a lesser extent, Geikie to recognize the Moine Thrust Zone was their inability to differentiate mylonites from regional schists when a mylonite zone is parallel to the regional foliation (a problem that remains to this day). It was relatively easy to identify a mylonite associated with the Arnaboll (Lewisian) gneiss because there was a strong textural gradient between the undeformed centre and the deformed margins of the rock. This is not what happens at the Moine Thrust which, in the Eriboll area, can juxtapose the Arnaboll gneiss and the overlying Moine schists. The contact is marked by the variegated schists or phyllitic mylonites of Lapworth (1885a) or frilled schists of Peach \& Horne (1888). An example of the variegated schists is shown in Figure 5a.

The variegated schists exhibit extensively developed quartz segregations, quartz veining and a strongly developed $c-c^{\prime}$ fabric (Passchier \& Trouw 2005). Lapworth regarded the fabric of the variegated schists as the product of reworking after initial mylonitization. That is, the shear bands seen
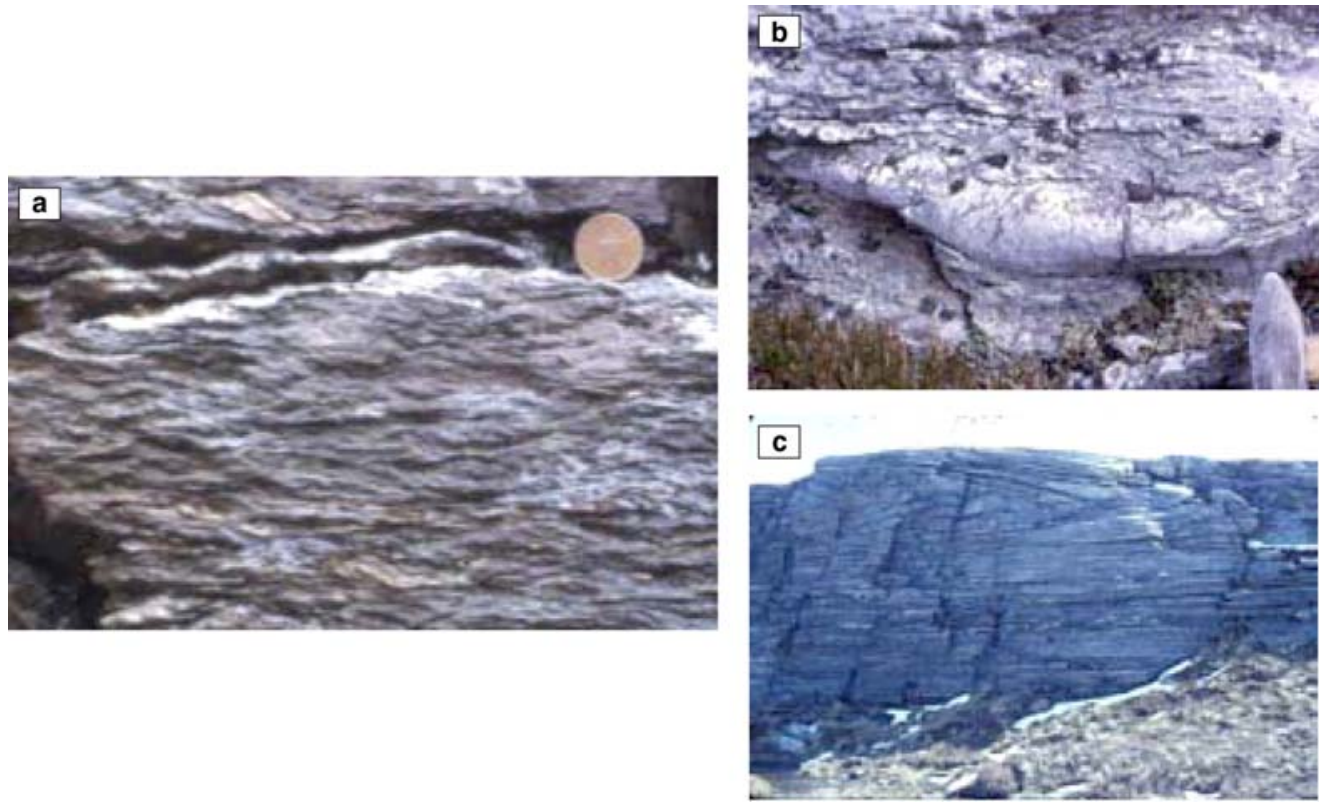

Fig. 5. Features associated with the Moine Thrust in the Ben Arnaboll-Eriboll area. (a) The variegated schist, phyllitic mylonite or Oystershell rock. (b) Sheath folds in the platy quartz mylonite at the contact between the variegated schists and the Moine mylonites. The regional WNW-ESE lineation is folded over the nose of the sheath fold in the centre of the photograph. (c) Isoclinal recumbent fold in the transition zone between the Moine mylonites and the Moine schists. The fold axes are parallel to the regional ESE plunging stretching/mineral lineation (see text). Mylonite zones develop along the attenuated limbs of the folds. 
in Figure 5a are R-shears reworking an earlier formed mylonitic fabric and are also reworking earlier generations of R-shears as they back rotated into mechanically harder orientations. There are multiple generations of quartz veining associated both with the initial mylonite fabric and with the later reworking by sequential generations of $\mathrm{R}$-shears to form the $\mathrm{c}-\mathrm{c}^{\prime}$ fabric.

Above the variegated schists are the quartz mylonites of Lapworth or the slaty schists of Peach \& Horne (1888) (Figs 5b \& 6a). These have a marked WNW-ESE-trending stretching lineation which is folded around extensively developed sheath folds; the nose of one such fold is shown in Figure 5b. They can have the typical knife-sheath profile of the first named sheath folds (Carreras et al. 1977). They tongue out in the direction of the stretching lineation and may be refolded by a new generation of asymmetric S-folds with their axes initially perpendicular to the lineation. These in turn may tongue out and be re-folded to create complex deformation patterns giving the false impression of a multi-event deformation. The quartz mylonites have a strong asymmetric, single girdle quartz $c$-axis fabric (Fig. $7 b$ ) that differs from the type two cross girdle fabric (Fig. 7a) from quartz bands in the mylonite adjacent to the Arnaboll thrust at Lapworth's locality (see also Law et al. 1984, 1986; Law \& Johnson 2010). The difference in quartz $c$-axis fabric types is thought to reflect the temperature sensitivity of dislocation slip systems in quartz (see White et al. 1982); the deformation temperature being lower during production of mylonites in the Arnaboll thrust than for those above the Moine Thrust. The factors affecting the transitions in quartz $c$-axis fabric types are discussed in detail by Law \& Johnson (2010).

The quartz mylonites above the variegated schists gradate into the flaggy schists of Peach et al. $(1884,1885,1888,1907)$, which in turn then gradate into the augen schists of Lapworth. As stated previously, both have mylonitic microstructures (Fig. 6b, c, respectively) and asymmetric single girdle $c$-axis quartz fabrics (Fig. 7c, d, respectively). Above these are the tightly folded and variably mylonitized schists (Fig. 5c) that form a wide transition zone to the Moine schists (Evans 1984). Fold axes within the transition zone generally parallel the stretching/ mineral lineation (see below).

Lapworth (1885a) regarded the schists, like those shown in Figure $5 \mathrm{c}$, as an assemblage of rocks 'so interfolded and interfelted together, that they can never be separated in the field and must be mapped simply as 'metamorphic'. Lapworth (1885a) and Peach et al. (1884, 1888) described the metamorphic process that produced these schists as being, essentially, a mechanical metamorphism which was more complete than the mechanical metamorphism that produced the mylonites (chiefly Peach et al. 1884, 1885). Lapworth (1885a) indicated that a combination of temperature gradient, strain rate gradient and a gradual change from a cataclastic deformation process to a plastic one had produced a gradational change from Moine mylonites to Moine schists. Peach et al. $(1884,1888)$ placed greater emphasis on a temperature gradient inducing greater crystallization to produce the schists.

There is no sharp boundary between Moine mylonites and Moine schists and where it is mapped can be a subjective choice. Generally, the boundary has been mapped further into the Moine schists by successive researchers (compare Peach \& Horne 1884; with Wilson 1953; Soper \& Wilkinson 1975; Evans 1984; Evans \& White 1984; British Geological Survey 2000; Holdsworth et al. 2007; Law \& Johnson 2010).

The gradational boundary between the Moine mylonites and Moine schists at Eriboll was studied by Evans (1984) and Evans \& White (1984). They pointed out that the mylonites passed into a wide zone of Moine schists characterized by isoclinal recumbent folds with fold axes parallel to the stretching/mineral lineation (Fig. 5c). The limbs were attenuated and sheared out to form mylonite zones exhibiting $\mathrm{c}-\mathrm{c}^{\prime}$ and s-c fabrics. The quartz grains in these zones exhibited well developed asymmetric single girdle $c$-axis fabrics similar to those shown in Figure $7 \mathrm{c}$, d. The asymmetry of the single girdles displayed by the $c$-axis fabrics characteristically indicates a WNW transport direction. Intriguingly, the quartz grains in the cores of the folds have a relaxed/recrystallized microstructure but retain a less pronounced single girdle $c$-axis fabric pattern (see Evans 1984; Evans \& White 1984) which is also asymmetric in the WNW transport direction. The asymmetry provides a kinematic link between the structures in the Moine schists and in the mylonites. The net result is that there is produced, in the transition from Moine mylonite to Moine schist, a broad zone of rocks, the transition zone of Evans (1984), consisting of a number of strands of mylonitized rock anastomosing around the fold hinges where less mylonitized rock is preserved (see Fig. 5c).

The above inter-relationship between the sheared, mylonitized limbs of the recumbent folds and preserved fold hinges continues east with the spacing between the mylonite zones increasing as the tightness of the fold hinges decreases and the wavelength of the recumbent folds increases. This spatial relationship continues until a major regional mylonite zone, the Half Way House Zone (Evans 1984) or the Achiniver Zone (Thrust) (Holdsworth et al. 2007) is encountered (see Fig. 2). The same 

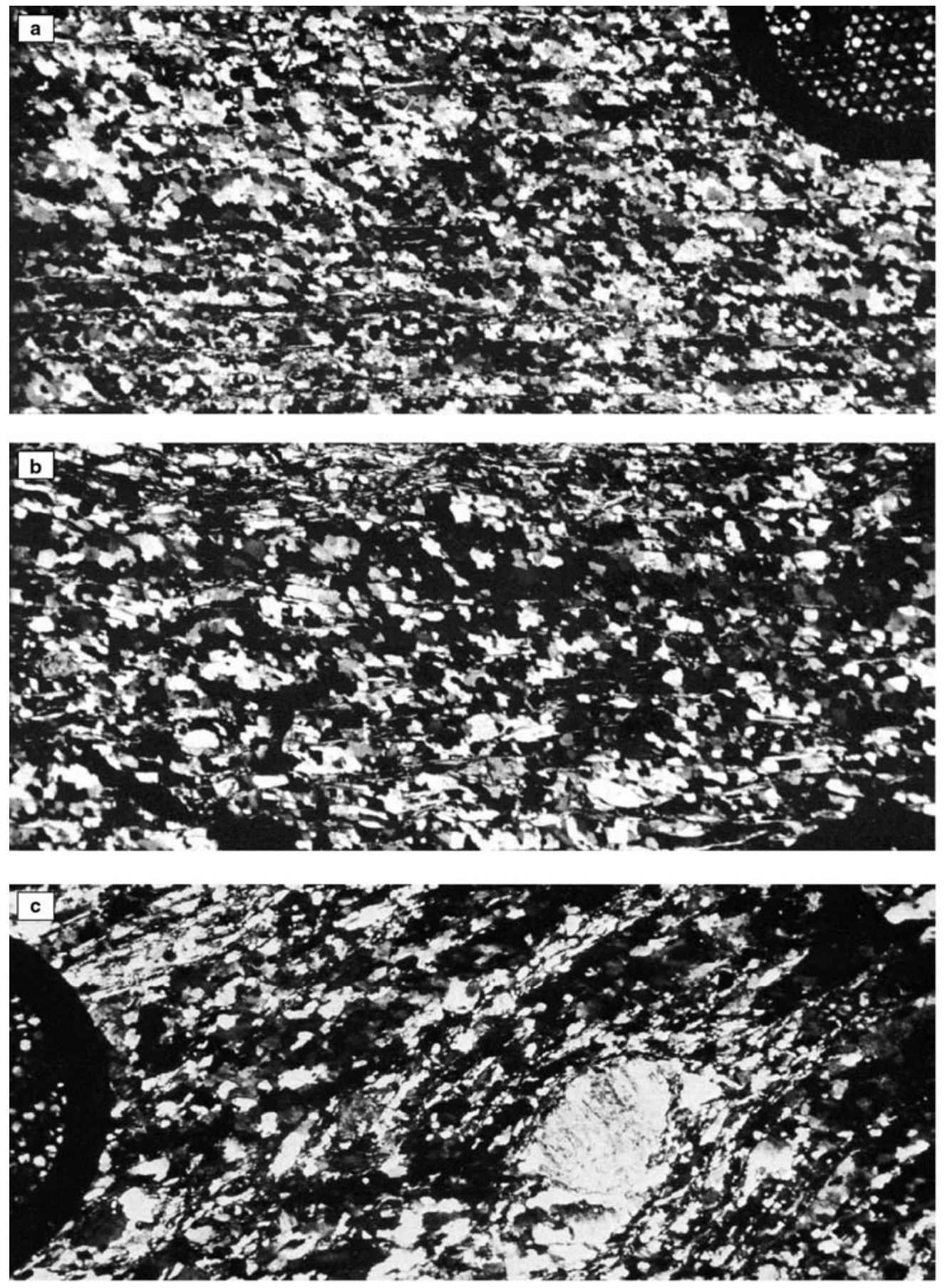

Fig. 6. Examples of typical microstructures from mylonites associated with the Moine Thrust in the Ben Arnaboll-Eriboll area. (a) Platy quartz mylonite adjacent to the variegated schists. (b) Typical Moine mylonite. (c) Augen mylonite from within the mylonitized Moine schists (Lapworth's augen schists). (Scale grid has a diameter of $3 \mathrm{~mm}$; tectonic transport/mechanical movement is to the WNW and is to the left for each photo micrograph. Specimens were cut perpendicular to foliation and parallel to the WNW-ESE trending stretching/mineral lineation, viewing is to the NNE.) 
(a)

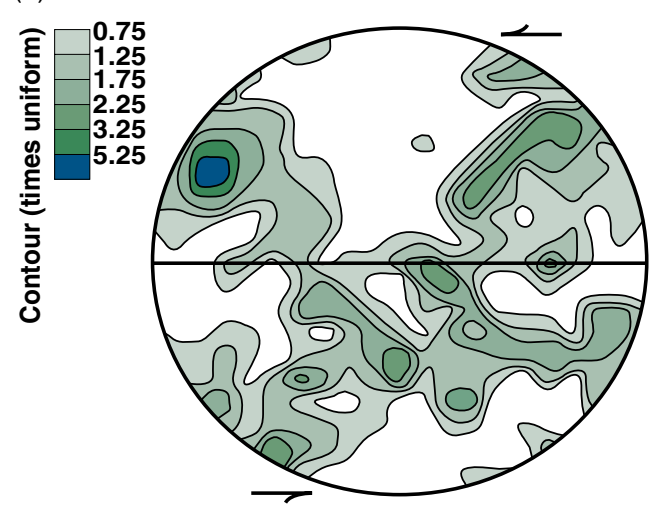

(c)

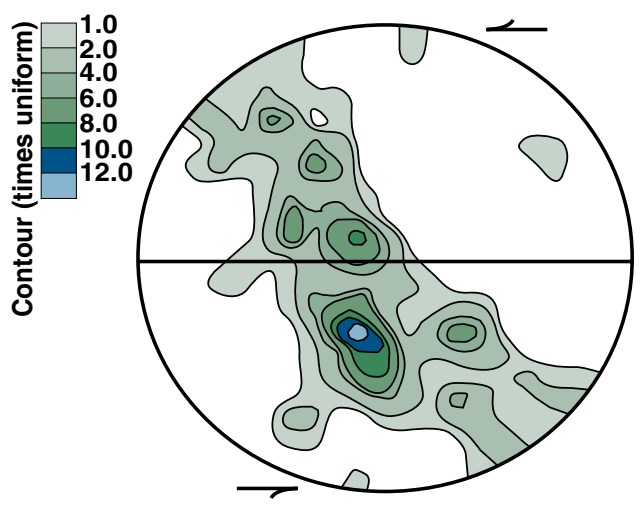

(b)

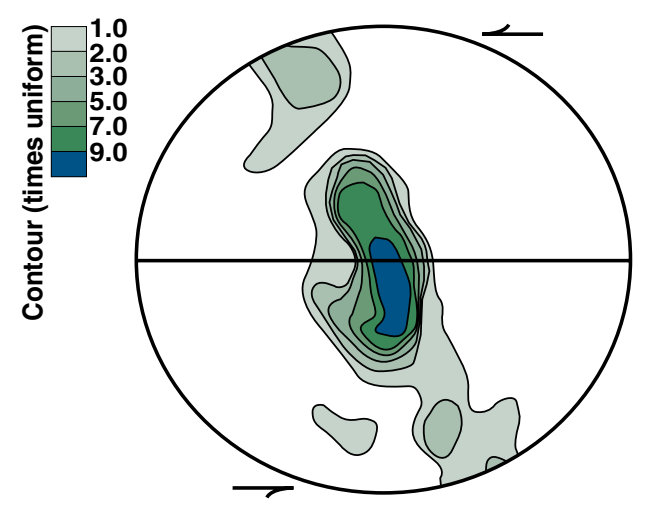

(d)

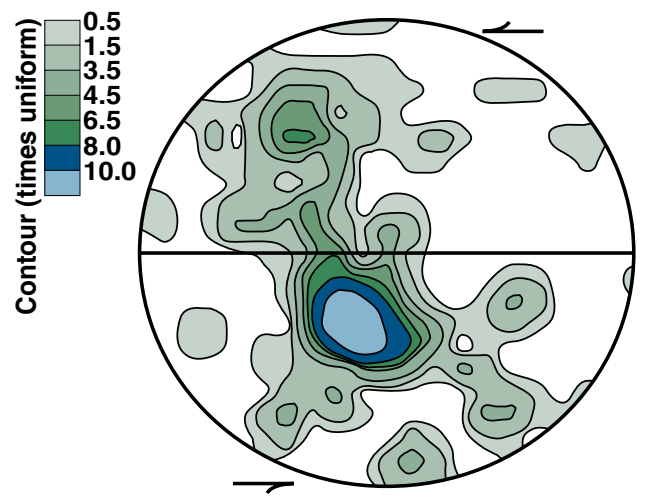

Fig. 7. Typical quartz $c$-axis fabrics associated with the Moine Thrust Zone in the Ben Arnaboll-Eriboll area (assembled from White et al.1982). (a) A type two cross girdle fabric from a coarser quartz rich band as shown in Figure $4 \mathrm{f}$ near the structural base of the sheared Lewisian at Lapworth's outcrop. (b) A sharp single girdle fabric from a platy quartz mylonite (see Fig. 6a). (c) A single girdle fabric from a typical Moine mylonite (see Fig. 6b). (d) A diffuse single girdle fabric from an augen mylonite (see Fig. 6c). (Tectonic transport/mechanical movement is to the WNW and is to the left for each diagram. Specimens were cut perpendicular to foliation and parallel to the WNW-ESE trending stretching/mineral lineation, viewing is to the NNE.)

trend continues to the east of the Achiniver Zone with less deformed schistose cores preserved between more widely spaced anastomosing mylonite zones until the next major shear, the Ben Hope Zone (Slide or Thrust) is encountered (Fig. 8). The quartz $c$-axis fabrics of the mylonites in these zones are characteristic of Moine mylonites (compare Fig. 9 with Fig. 7; see also Law \& Johnson 2010), with the intensity of the fabric increasing in the more intensely foliated bands in a given zone (see Fig. 9). The same fabrics from the intervening schists are more random (Fig. 9c). These and similar schists in the Eriboll to Ben Hope area exhibit quartz grains which show marked evidence for grain growth. However they retain internal strain features which can be related to dislocation sub-structures (Evans 1984). Evans associated the fabric and microstructures of the quartz grains within the intervening schists with localized relaxation as deformation concentrated in the footwall of the Moine Thrust pile. The result is a regionally zoned distribution of quartz microstructures reflecting temporal variations in shear zone activity and intensity. A similar conclusion had been reached previously by Read (1931) and by Macgregor (1948); both had noted zoned distributions of quartz microstructures in the Moine schists. They described the relaxed quartz grains as being granulated (Read 1931) or tessellated (Macgregor 1948, 1952).

The Ben Hope Zone was first identified, and traced out, by Peach et al. (1888) from the coast 


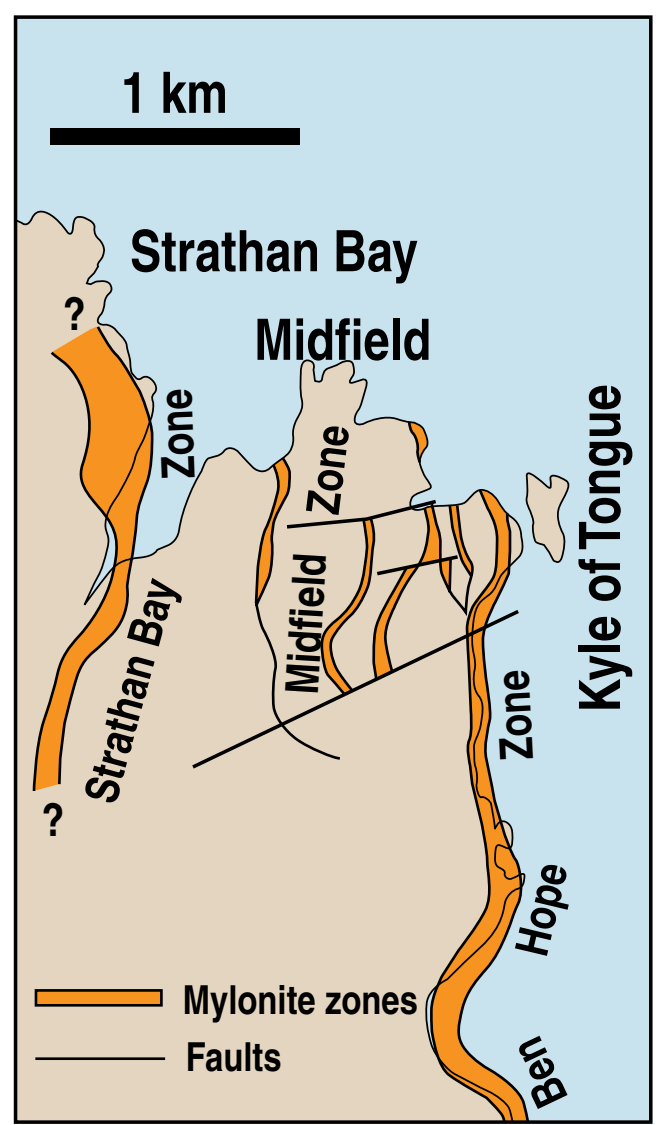

Fig. 8. Sketch map showing the mylonite zones in the Moine schists from the poorly exposed A' Moine in the area between the Kyle of Tongue and Strathan Bay, as indicated in Figure 2. (Modified from Bretan 1985, drawn by Ryan Thigpen.)

north of the Kyle of Tongue southwards around the west facing slope of Ben Hope. They recognized a similar but larger feature, the Naver Zone, farther to the east (see Fig. 1). It is now known that these zones form boundaries between the major sub-divisions of the Moine (see Fig. 1 and Thigpen et al. 2010).

\section{Early recognition of 'divisional planes' in the Moine schists between the Moine Thrust Zone and the Ben Hope Slide (Thrust) Zone in the Eriboll area}

Peach et al. (1888) recognized planar structures in the Moine schists between the Moine Thrust Zone and the Ben Hope Zone or Slide and across to the Naver Zone (see Fig. 1). They wrote that there were major divisional planes within the Moine schists which truncated minor ones "like the major and minor thrusts in the displaced Silurian strata' and that 'as the schists were being driven forward, the materials were piled on each other to an enormous thickness'. They went on to note that:

1. the first divisional planes in the Moine schists were frequently truncated by subsequent thrusts;

2. the divisional planes had a lineation parallel to those in the crush rock and mylonitic schists and were post Silurian (i.e. post the CambroOrdovician sediments);

3. the flaggy gneisses and crystalline schists along the divisional planes differ from the mylonites under the Moine Thrust-plane because their matrix is holocrystalline due to the higher temperatures resulting from a more rapid rate of movement (a first description of shear heating).

The first divisional planes that Peach et al. (1888) were describing are 'slide zones' as subsequently defined by Bailey (1910). They are now called ductile shears or ductile thrusts. Bailey (1910) noted that a slide zone was the result of thrusts replacing the attenuated limbs of regional recumbent folds leaving preserved cores between successive slides. The slides were not planar but zonal and the result of plastic deformation at high metamorphic temperatures; see review by Hutton (1979). They were subsequently recognized in the Moine schists as high temperature syn-metamorphic ductile shear zones (e.g. see Tanner 1971; Rathbone \& Harris 1980; Powell et al. 1981). The Achiniver, Ben Hope and Naver Zones above fit Bailey's description of slide zones. The deformed rocks within the slide zones are, by definition, mylonites but often are not recognized as such because of their coarse grain size. However, kinematic indicators, including asymmetric quartz $c$-axis fabrics, can be used to identify mylonites in the Moine schists irrespective of the grain size of the mylonites (Evans 1984; Evans \& White 1984; Bretan 1985; Grant 1989; Holdsworth \& Grant 1990). They found that the asymmetric quartz fabrics were preserved even when post tectonic grain growth had occurred in the recrystallized Moine mylonites.

Clough, in a written comment to the paper of Bailey (1910), stated that there are structures similar to those in a slide zone not far to the east of the Moine Thrust. The structures described above by Evans (1984) and Evans \& White (1984), in the transition zone between Moine mylonites and the Moine schists, are those of a slide zone and suggest that the Moine Thrust Zone at Eriboll was initially located in such a structure. It is interesting to recall that Peach \& Horne (1884) and especially Lapworth (1883) placed the Moine 

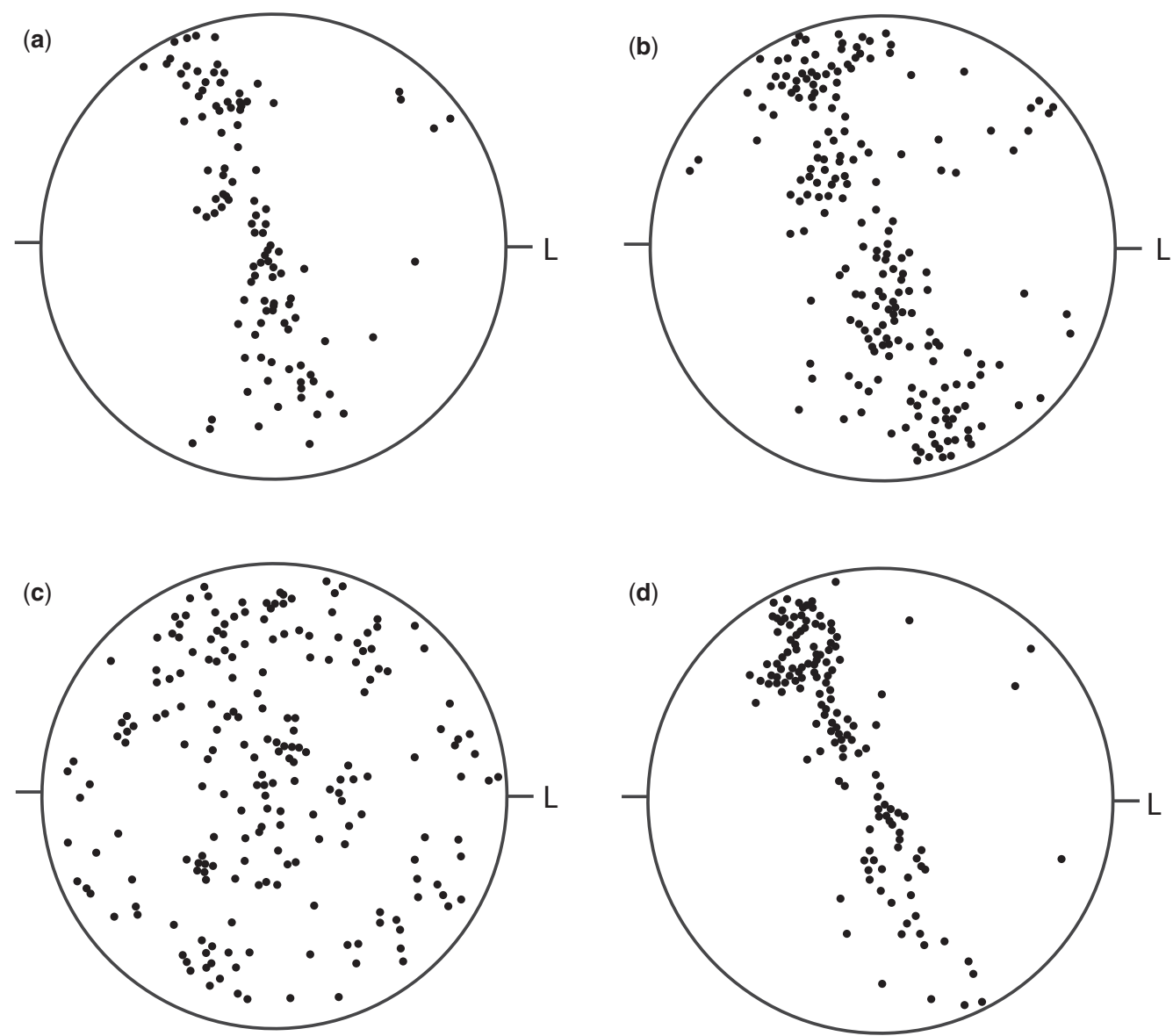

Fig. 9. Typical $c$-axis quartz fabrics from the mylonite zones and Moine schists in the Kyle of Tongue-Strathan Bay area as shown in Figure 8. (Assembled from Bretan 1985.) (a) From a more intensely foliated mylonite band in the Strathan Bay Zone. (b) From a more weakly foliated mylonite band in the Strathan Bay Zone. (c) From the Moine schists between the Strathan Bay and Midfield Zones. (d) From a more intensely foliated mylonite band within the Midfield Zone. (Tectonic transport/mechanical movement is to the WNW and is to the left for each diagram. Specimens were cut perpendicular to foliation and parallel to the WNW-ESE trending stretching/mineral lineation, viewing is to the NNE.)

Thrust Zone at Eriboll in the sheared out limb of what Lapworth referred to as a major 'overfold' and which would fit Bailey's definition of a slide.

Summarizing this and the previous section, the Moine schists are divided into major sub-divisions by mylonitic slide zones. Within the sub-division bounded by the Moine Thrust Zone and the Ben Hope Slide are anastomosing arrays of mylonite zones, on different scales, marking ductile shear zones (thrusts) which become more closely spaced as the Moine Thrust Zone is approached. The more closely spaced mylonite zones preferentially locate in the most attenuated limbs of recumbent folds which have their axes parallel to the stretching lineation in the mylonites. Within the Moine Thrust Zone a geometrical and genetic relationship between folds and mylonite zones (thrusts) can exist as first recorded by Peach \& Horne (1884) and Lapworth (1885a). This relationship can cause the internal mylonite zones to anastomose. This in turn can create problems when tracing and naming a particular mylonite, or shear, zone.

\section{Time span in generating a mylonite microstructure}

There is often the taciturn assumption that a mylonite is generated in a geologically instantaneous time frame. Peach et al. $(1884,1885,1888)$ were aware that different thrusts at Eriboll were tectonically active at different times and that the activity 
on a given thrust could be intermittent. In spite of this the stretching/mineral lineation produced within the associated mylonites had a constant orientation to which kinematic indicators were uniquely related and gave a unique sense of tectonic transport (see also Law \& Johnson 2010, fig. 5a). That is, the kinematic framework exhibited by the mylonites was unique and coherent, but was produced over an extended period of time. Lapworth was more specific about an extended time period for development of the variegated schists (see above). He was aware that in the variegated schists at Eriboll, a mylonitic microstructure was produced first and then had to be reworked, along with generations of added quartz veins, by the $\mathrm{R}$-shear bands to produce the $\mathrm{c}-\mathrm{c}^{\prime}$ fabric that characterizes their final macro- and microstructure.

The question is: how long did it take to produce the mylonite microstructure and then to rework it into variegated schist or, of equal importance, how long did it take to produce Lapworth's mylonite sequence and each rock type in that sequence? We have techniques to date the crystallization of a mineral or rock that becomes involved in the mylonitization or a limited number of minerals that are produced during the mylonitization. But often these are closure dates, that is they represent the time that mineral passed through its blocking temperature. $\mathrm{Rb}-\mathrm{Sr}$ dating of white mica which had syntectonically crystallized in the Moine mylonites gave a sub-closure age of c. $430 \mathrm{Ma}$ (Freeman et al. 1998) with a span from 437 to $408 \mathrm{Ma}$. This is within the span from $c$. 440 to $410 \mathrm{Ma}$ for movement on the Moine Thrust Zone (Johnson et al. 1985; Kelley 1988; Dallmeyer et al. 2001).

In the case of the variegated schists, sub-closure temperatures from white mica syntectonically crystallized during production of the original mylonite texture and during shear band development would give an indication of the time span represented by formation of the overall texture. I know of no such study for mylonites associated with the Moine Thrust Zone. Such a study using the laser microprobe ${ }^{39} \mathrm{Ar} /{ }^{40} \mathrm{Ar}$ technique on mylonites, with a texture similar to the variegated schists, from Alpine shear zones in the Aegean area indicated a time span of $c .40$ million years in the production of the texture of a single thin section (Lips 1998; Lips et al. 1999).

Perhaps, when we look at a mylonitic microstructure we should ask ourselves - how long did it take to form and when did each component in the microstructure develop?

\section{Mylonite nomenclature and classification}

Lapworth (1885a) gave a simple definition of a mylonite based on field observations at Eriboll; namely it is a schistose rock associated with a dislocation (shear plane or zone) and produced by mechanical metamorphism resulting from the tectonically induced movement of adjacent rock masses relevant to one another as solid masses across that dislocation. He also published a sketch of what he regarded as a mylonite texture and sketches of related schistose textures that could result from mechanical metamorphism, namely a flaser, an augen and a granulitic texture (see Fig. 3). Peach \& Horne (1884) and Peach et al. (1888) noted that mylonites also tend to be characterized by a stretching lineation and by asymmetric internal structures induced by the movement. Lapworth (1885a, 1899; Page \& Lapworth 1888) and Peach et al. (1884, 1885, 1888) have provided information to help define and recognize a mylonite.

Within less than 50 years of Lapworth's definition, Knopf (1931) was to write that, since Lapworth's original publication, mylonites have been 'variously defined by different geological writers'. Christie (1960) observed that there was considerable confusion in the use of the term 'mylonite' because some authors had not adhered to Lapworth's definition whilst others were unaware of it. Time has not improved either the nomenclature or the classification of mylonites as indicated by Spry (1969) and by Snoke \& Tullis (1998). Nor has time improved awareness to Lapworth's writings on mylonites. Reference to material related to mylonites in Lapworth's books and to their contained sketches of mylonitic and related textures is rare. I became aware of his books through a reference to his first book made by Callaway in 1893 and have observed no reference to material in his books in more recent articles dealing with mylonite textures, nomenclature and classification.

The initial problems with nomenclature can be seen in the different views of Lapworth (1885a) and of Peach et al. (1888) with respect to the cause of the progression from mylonite to schist in the Moine Nappe. Both authors agreed that the grain refinement was by cataclasis and related the progression to an increase in the crystallization of the matrix (interstitial paste). Lapworth noted when the augen schists (augen mylonites) had been reached in the progression, the interstitial paste had crystallized out. He went on to relate the increased crystallization to a lesser differential motion between component particles (lower strain rate) and a greater chemical change due to a change in deformation process from cataclasis to plastic yielding. Peach et al. (1888) thought that the increase in the amount and prominence of crystallization of the paste or matrix was due an increase in temperature (albeit a form of shear heating) following initial cataclasis. Lapworth (1899) further confused the issue by clearly stating that a mylonite 
is a cataclasite. Teall (1887), when introducing the term 'cataclasite' into the British geological literature (see earlier section), followed Kjerulf's (1885) definition of the term, namely a cataclasite is a rock largely composed of fragments produced during the deformation of older rocks. The rocks which Teall was referring to were banded gneisses. In 1893, Bonney suggested that from an etymological viewpoint a mylonite should be referred to as a cataclasite and this appears to have been followed by Lapworth (1899) when he referred to mylonites, augen schists and flaser schists as cataclastic types of rock. Knopf (1931) followed Lapworth's example and wrote that a cataclasite is a foliated, cohesive rock with easily recognized fragments. In her scheme, a mylonite is a cataclasite and vice versa. Summarizing the above, by the end of the 19 th and beginning of the 20th centuries, the terms 'mylonite' and 'cataclasite' were being used synonymously and this continued as seen in Geikie et al. (1940, 1953).

Views similar to those of Peach et al. (1888) were followed until the mid 1970s and formed the basis for mylonite classification, as seen in Geikie et al. (1940, 1953), Spry (1969) and in Higgins (1971). Geikie et al. set up an embryonic classification scheme in which both mylonites and cataclasites were described as 'cataclastic rocks'. Mylonites were foliated and cataclasites were not foliated or only weakly foliated; the one could pass 'by insensible gradations' into the other. Spry (1969) reviewed the literature, but overlooked Geikie et al. (above). He set up a simple classification scheme based on the amount of matrix produced by the crushing and on the texture of the rock. His mylonitic rocks were characterized by a foliated matrix and differed from his cataclasitic rocks which had a massive or unfoliated matrix. Spry followed the example of Hsu (1955) in regarding cataclasites as being unfoliated, cohesive fault rocks. But should we use the term cataclasite for a non-foliated coherent fault rock? Given its common usage and the desire to prevent further confusion, it is recommended that Spry's sub-division is retained but that it has no genetic connotation. That is, a mylonite is a foliated coherent fault rock and a cataclasite is an unfoliated coherent fault rock and cataclasitic and crystal plastic deformation processes can contribute to the formation of both.

Spry (1969) went on to sub-divide each type of fault rock on the amount of matrix present and in doing so followed a point made by Teall (1918) who recorded that he could no longer deduce the protolith within a mylonite microstructure and used this to distinguish a mylonite from a sheared gneiss. The mylonitic sequence proposed by Spry is: protolith - protomylonite (10-50\% matrix) mylonite (50-90\%) - ultramylonite (90-100\%).
For the field geologist this means that for a protomylonite - protolith can easily be recognized, and mylonite - protolith can also be recognized, but ultramylonite - protolith cannot be recognized. Teall's mylonite would correspond to Spry's ultramylonite. The same distinctions hold for Spry's unfoliated cataclastic sequence which runs: protolith-protocataclasite-cataclasite-ultracataclasite.

Spry (1969) followed Peach et al. (1888) in regarding recrystallization, or neo-mineralization, of the mylonitic matrix as being late and masking the original cataclastic nature of mylonites. He used the term 'blastomylonite', first used by Sander in 1912 (see Knopf 1931) if the masking was near complete. Knopf related a blastomylonite to Lapworth's sequence and placed it between Lapworth's augen schist (augen mylonite) and Moine schist. Microstructurally, it would correspond to Figure 6c, but with a coarser matrix. Christie (1960, 1963), in his studies of the Moine mylonites in the Assynt area, thought that a 'blastomylonite' was equivalent to Lapworth's augen schist (augen mylonite) (see Figs $3 b \& 6 c$ ) or to the variegated schist (Fig. 5a). Higgins (1971), in his definition of a blastomylonite, placed greater emphasis on the first appearance of recrystallized grains and defined a blastomylonite as a fine grained mylonite or ultramylonite produced by concurrent cataclasis and recrystallization/neo-mineralization. If this view is followed, then the rock shown in Figure $4 \mathrm{f}$ or in Figure $4 \mathrm{e}$ or even in Figure $4 \mathrm{~d}$ is a blastomylonite (see also White et al. 1982). Sander's own figure of a blastomylonite (Sander 1970, fig. 102) resembles Figure 4e. There has been a significant lack of consistency in the application of the term 'blastomylonite'.

The approach to mylonite classification changed with the observation by Bell \& Etheridge (1973) and by White $(1973 a, b, 1976)$ that grain refinement to form mylonites could occur by dynamic recrystallization during crystal plastic deformation as well as by cataclasis. They had rediscovered Teall's wheel. This produced classification schemes that emphasized the role of crystal plastic deformation processes, and grain refinement by recrystallization, in mylonite production. It led to a clear separation between cataclasites and mylonites based on deformation processes and, in turn, on temperature and pressure conditions at the time of deformation. The first example was the scheme of Sibson (1977) who added deformation conditions as expressed by seismic and aseismic behaviour to Spry's textural classification. Subsequent classifications have incorporated increasingly sophisticated elements of crystal plastic deformation, recovery and recrystallization processes in classification schemes (Wise et al. 1984; Schmid \& Handy 1991). In general, the resulting schemes emphasize 
a clear depth cut-off between cataclasite, above, and mylonites, below, the $c .300{ }^{\circ} \mathrm{C}$ isotherm (see Snoke $\&$ Tullis 1998). Such schemes have three problems which are listed below.

a) They cease to be field based and cannot be used as a mapping tool.

b) They cannot be equated to what is seen in Lapworth's section and do not fit well into the gradational progression from mylonite to schist which Lapworth noted at Eriboll.

c) They ignore the conclusion reached separately by Teall (1885, 1902 and 1918), Lapworth (Page \& Lapworth 1888; Lapworth 1899) and Geikie (1903), that cataclastic deformation processes with grain refinement by comminution plus attendant or subsequent grain growth and plastic deformation processes with grain refinement by granulation (recrystallization) are the two end members of the deformation processes that produce mylonites. In most instances both processes will be involved in the production of a mylonite and the two end members grade 'imperceptibly' into one another. How the gradation occurs is influenced by the rock mix within the mylonitic mill and later additions, including water, to that mix as well as the deformation conditions, which may be variable, within the mill.

In Lapworth's section at Eriboll, the initial grain refinement was by cataclasis as preserved in the low strain hanging wall margin of the Arnaboll Thrust. The ultramylonites are in the high strain footwall section; that is where deformation and presumably uplift has concentrated. In such circumstances cataclasis predated mylonitization and occurred at a greater depth, the switch from cataclasis to crystal plastic deformation processes being due to the development of a mechanically weaker mineral assemblage. Fracturing and vein formation is common throughout the variegated schists and continues through the Moine mylonites (Evans 1984) with multiple generations of quartz veins being reworked via recrystallization into the mylonites until the veins can no longer be identified on the basis of microstructure and quartz $c$-axis fabrics. The same happens to quartz-feldspar, epidote and carbonate veins throughout the Moine Thrust Zone. The continually changing composition of what goes into a mylonitic mill affects how the ingredients in the mill deform over the lifetime of the mill and this is not taken into account in classification schemes based on deformation mechanisms. As stated above, the use of Spry's simple descriptive classification scheme for mylonites (foliated) and cataclasites (non-foliated) along with Lapworth's field based definition, as given above, is recommended. If this is done, both the classification and definition of a mylonite are freed from genetic parameters which are often subjective. The IUGS have followed a somewhat similar approach (see Brodie et al. 2007) although subjectivity remains.

Finally, where does a blastomylonite fit? Currently it is described as a mylonite showing pronounced grain growth (Sibson 1977) or pronounced static (post tectonic) recrystallization (Passchier \& Trouw 2005). The two processes differ as the former is a re-adjustment of the grain structure without involving a phase of new grain nucleation as required for recrystallization. However the end product of both processes is the same, namely, the schistose appearance of the mylonite becomes more granular or gneissic. The use of the pre-fix 'gneissic' to distinguish such mylonites, as indicated by Lapworth (Page \& Lapworth 1888; Lapworth 1899) removes genetic connotations associated with the term 'blastomylonite' and the term should not be used, especially given its inconsistent use in the past.

\section{Conclusion}

Many lessons were learnt and many can still be learnt from the studies undertaken, in the 19th century, on the mylonites at Eriboll and elsewhere within the Moine Thrust Zone. The works of Lapworth, of Peach, Horne and co-workers and, to a lesser extent, of Callaway, Teall and Geikie, are of special importance. A personal choice of some lessons is listed below.

1. The first, and most important, lesson is the value of high quality field-work/mapping guided by what is present and not what fits an 'in vogue' hypothesis. It would appear that Murchison and Geikie followed the latter approach and they were proven wrong a lesson well worth heeding. The field is geology's fundamental laboratory by which all geological hypotheses, irrespective of their origin, must ultimately be constrained.

2. Also of importance is the research of our predecessors. Much of it is of high quality based on sound observation and logical scientific deduction. If we neglect such research we not only run the likelihood of 'rediscovering the wheel' but can also inhibit the advancement of our science. The controversies that have been associated with many aspects of mylonite studies, for example, definition, nomenclature, recognition, associated deformation processes, kinematics, flow and tectonic transport directions and the significance of stretching/mineral lineations, largely have arisen because of failure to take into account what was written by people 
such as Lapworth, Teall, Peach and Horne and co-workers and Geikie.

3. Lapworth gave a simple definition of a mylonite which remains adequate, namely it is a schistose rock associated with a dislocation (shear or fault zone) and produced by mechanical metamorphism (shear and fault zone related metamorphism) resulting from the tectonically induced movement of adjacent rock masses relevant to one another as solid masses across that dislocation. Peach, Horne and coworkers noted that mylonites also tend to be characterized by a stretching and/or mineral lineation and by asymmetric internal structures, to which crystallographic fabrics can be added, induced by the movement. Taken together, they have provided sufficient information to define a mylonite and have given criteria to aid the recognition of a mylonite in the field.

4. Lapworth's original definition, and later supplementary additions, should form the basis for nomenclature and classification schemes. Spry has presented a simple scheme which takes into account both foliated fault rocks (mylonite series) and non-foliated fault rocks (cataclastic series) and which should be used so long as no genetic connotations are implied. The term 'blastomylonite' has been used so inconsistently that its use should be discontinued.

5. Lapworth, Teall and, later, Geikie realized that both cataclastic and crystal plastic deformation processes can produce a mylonite. They saw these as the two end member processes which can imperceptibly grade into one another; most mylonites and cataclasites will result from interplay between both. Lapworth's outcrop at Ben Arnaboll shows the complexity of such interplay between these processes; a complexity that we must take into account when modelling the rheology of mylonite zones in crustal and upper mantle environments.

6. The following three questions, first posed by Teall in 1885, relating to the interplay between cataclastic and crystal plastic deformation processes during mylonitization remain as relevant today as they did then.

a) Under what conditions is the deformation accompanied by a crushing of the individual constituents?

b) Under what conditions is it accompanied by entire molecular rearrangement (crystal plastic deformation and recrystallization)?

c) Under what conditions do these two more or less opposites occur at the same time?
7. We should heed the observation by Lapworth and by Huddleston that external material, including water, can be continually added to the mylonitic mill during the production of a mylonite.

8. Peach, Horne and co-workers were the first to identify and define a stretching lineation in mylonites from Eriboll. They established that its orientation was uniquely related to the direction of tectonic transport by using the thrust geometries and by the first use of shear sense indicators. It would be another hundred years before the use of shear sense indicators became a widely used technique in structural studies.

9. Peach, Horne and co-workers appear to have used the kinematic relationship between a stretching lineation and associated shear sense indicators to successfully identify shear/ mylonite zones in the Moine schists to the east of the Moine Thrust Zone in the Eriboll area. In spite of this, the identification of mylonite zones within regional schists, especially if they are parallel to the regional foliation, has been, and still can be, controversial.

10. Lapworth and Peach, Horne and co-workers realized that not only could there be a temporal difference in the tectonic activity of different mylonite zones in a given area or structure (e.g. the Moine Thrust Zone) but also within an individual mylonite zone. That is, not all mylonite zones associated with a major shear zone structure were active at the same time and within a given mylonite zone activity could be intermittent or protracted. This is a lesson we are still to learn. The next time we hold a mylonite hand specimen or look at a thin section of a mylonite, we should ask the following: how long did it take to produce the overall mylonitic texture and when did the individual components in that texture form?

11. Finally, Lapworth's mylonite locality at Ben Arnaboll illustrates the futility associated with relying on a single hand specimen or single thin section to fully characterize the processes that went on within the mill that produced a mylonite or an ultramylonite from its protolith, unless the sample or thin-section covers the entire mylonite zone under study. But even then caution must be exercised.

I especially thank R. Law for his comments and editorial assistance. He and R. Thigpen helped with figures and provided Figures 1 and 2. R. Law is also thanked for his patience as this contribution evolved from draft to final manuscript. I thank M. Johnson and P. Smith for constructive reviews which made me think more deeply about 
issues I had skimmed, P. Smith for helping to track down Lapworth's books and for providing a copy of the relevant chapters, C. Fleet of the NLS for assistance with the early OS maps of Scotland and R. Butler for making available a draft of his paper which appears in this volume. The staff, especially Guido Tresoldi, in the library at the School of Earth Sciences, Melbourne University is thanked for assistance when tracing early literature upon which this article is based and for introducing me to the School's Vallance collection. This article is written in remembrance of those forebears who were sent, through banishment or clearance, from the Highlands and Islands.

\section{References}

Adams, F. D. \& Nicolson, J. T. 1901. An experimental investigation into the flow of marble. Philosophical Transactions of the Royal Society, A195, 363-402.

Allison, I., MAy, F. \& Strachan, R. A. (eds) 1988. An Excursion Guide to the Moine Geology of the Scottish Highlands. Scottish Academic Press, Edinburgh.

ANDERSON, E. M. 1948. On the lineation and petrofabric structure, and shearing movement by which they have been produced. Quarterly Journal Geological Society, London, 114, 99-128.

ANDRADE, E. N. DA C. 1910. On the viscous flow in metals and allied phenomena experimental. Proceedings of the Royal Society, A84, 329-342.

ANDRADE, E. N. DA C. 1914. The flow of metals under large constant stresses. Proceedings of the Royal Society, A90, 1-12.

BArber, A. J. 1965. The history of the Moine Thrust Zone, Lochcarron and Lochalsh, Scotland. Proceedings of the Geologists Association, 76, 215-242.

BAILEY, E. B. 1910. Recumbent folds in the schists of the Scottish Highlands. Quarterly Journal of the Geological Society, London, 66, 586-620.

BaIley, E. B. 1935. Tectonic Essays Mainly Alpine. Clarendon Press, Oxford.

BALK, R. 1952. Fabric of quartzites near thrust faults. Journal of Geology, 60, 415-430.

BASSETT, D. A. 1991. Roderick Murchison's The Silurian System: A sesquicentennial tribute. In: BASSETT, M. G., LANE, P. D. \& EDWARDS, D. (eds) The Murchison Symposium. The Palaeontological Association London. Special Papers in Palaeontology, 44, 7-90.

Bell, T. H. \& Etheridge, M. A. 1973. The microstructure of mylonites and their descriptive terminology. Lithos, 6, 337-348.

Bonney, T. G. 1880. Petrological notes on the vicinity of the upper part of Loch Maree. Quarterly Journal of the Geological Society, London, 35, 93-108.

Bonney, T. G. 1883. Notes on a series of rocks collected by C. Callaway. Quarterly Journal of the Geological Society, London, 39, 414-422.

Bonney, T. G. 1886. Anniversary address of the President. Proceedings of the Geological Society, London, 42, 55-115.

Bonney, T. G. 1893. On secondary development of biotite and hornblende in crystalline schists from the Binnenthal. Quarterly Journal of the Geological Society, London, 49, 104-113.
BRETAN, P. G. 1985. Deformation processes within mylonite zones associated with some fundamental faults. Unpublished $\mathrm{PhD}$ thesis. University of London.

British Geological Survey. 2000. Loch Eriboll. Scotland Sheet 114W. 1:50000. Solid Geology. British Geological Survey, Keyworth.

Brodie, K. H., Fettes, D. J., Harte, B. \& Schmid, J. A. 2007. Structural Terms Including Fault Rock Terms. IUGS Subcommission on the Systematics of Metamorphic Rocks (SCMR).

BUTLER, R. W. H. 1982a. The terminology of structures in thrust belts. Journal of Structural Geology, 4, 239-245.

Butler, R. W. H. 1982b. A structural analysis of the Moine Thrust zone between Loch Eriboll and Foinaven, NW Scotland. Journal of Structural Geology, $\mathbf{4}$ 19-29.

BUtLER, R. W. H. 1987. Thrust sequences. Journal of the Geological Society, London, 144, 619-634.

Butler, R. W. H. 2000. A short walk with Archibald Geikie. Geoscientist, 10, 4-6.

Butler, R. W. H. 2004. The nature of 'roof thrusts' in the Moine Thrust Belt, NW Scotland: implications for the structural evolution of thrust belts. Journal of the Geological Society, London, 161, 849-859.

ButLer, R. W. H. 2007. Field Excursion A-Loch Eriboll and Durness region. In: STRACHAN, R. A. \& THIGPEN, J. R. (eds) Continental Tectonics and Mountain Building-the Peach and Horne Meeting. A Guide to Field Excursions, pp. 37-52, Joint meeting of the Geological Society of London (an Arthur Holmes meeting) and Geological Society of America to celebrate the centenary of the Peach and Horne 1907 Geological Survey of Scotland memoir on 'The Geological Structure of the Northwest Highlands of Scotland, Ullapool, Scotland. 12-19 May 2007.

BUTLER, R. W. H. 2010. The role of thrust tectonic models in understanding structural evolution in NW Scotland. In: LAW, R. D., Butler, R. W. H., Holdsworth, R. E., Krabbendam, M. \& Strachan, R. A. (eds) Continental Tectonics and Mountain Building: The Legacy of Peach and Horne. Geological Society, London, Special Publications, 335, 293-320.

Callaway, C. 1881. The limestone of Durness and Assynt. Quarterly Journal of the Geological Society, London, 37, 239-245.

Callaway, C. 1882. The Torridonian Sandstone in relation to the Ordovician Rocks of the Northern Highlands. Quarterly Journal of the Geological Society, London, 38, 114-118.

Callaway, C. 1883a. The Highland problem. Geological Magazine, Decade 2, 10, 139-140.

Callaway, C. $1883 \mathrm{~b}$. The age of the newer gneissic rocks of the northern highlands. Quarterly Journal of the Geological Society, London, 39, 355-414.

Callaway, C. 1893. The origin of the crystalline schists in the Malvern Hills. Quarterly Journal of the Geological Society, London, 49, 398-425.

Carreras, J., Estrada, A. \& White, S. H. 1977. The effects of folding on the c-axis fabric development of a quartz mylonite. Tectonophysics, 39, 3-24.

Christie, J. M. 1956. The post-Cambrian thrusts of the Assynt Region. Unpublished $\mathrm{PhD}$ thesis, Edinburgh University. 
Christie, J. M. 1960. Mylonitic rocks of the Moine Thrust Zone in the Assynt region, North-West Scotland. Transactions of the Edinburgh Geological Society, 18, 93-166.

Christie, J. M. 1963. The Moine thrust zone in the Assynt Region, northwest Scotland. University of California Publications in Geological Sciences, 40, $345-440$.

Christie, J. M. 1965. The Moine thrust zone in the Assynt region, northwest Scotland [discussion]. Journal of Geology, 73, 672-681.

CowARD, M. P. 1982. Surge zones in the Moine thrust zone of NW Scotland. Journal of Structural Geology, 4, 247-256.

CowARD, M. P. 1983. The thrust and shear zones of the Moine Thrust Zone and the Scottish Caledonides. Journal of the Geological Society, London, 140, $795-811$.

CowARD, M. P. 1984. A geometrical study of the Arnaboll and Heilam thrust sheets, NW of Ben Arnaboll, Sutherland. Scottish Journal of Geology, 220, 87-106.

COWARD, M. P. 1985. The thrust structures of southern Assynt, Moine Thrust Zone. Geological Magazine, 122, 595-607.

CowARD, M. P. \& KIM, J. H. 1981. Strain within thrust sheets. In: MCClay, K. R. \& PRICE, N. J. (eds) Thrust and Nappe Tectonics. Geological Society, London, Special Publications, 9, 275-292.

Coward, M. P. \& PotTs, G. J. 1983. Complex strain patterns at frontal and lateral tips to shear zones and thrust zones. Journal of Structural Geology, 5, 383-399.

Cunningham, R. J. H. 1839. Geognostic account of the County of Sutherland. Transactions of the Highland and Agricultural Society, 13, 73-114.

Dallmeyer, R. D., Strachan, R. A., Rodgers, G., WATt, G. R. \& FRIEND, C. R. L. 2001. Dating deformation and cooling in the Caledonian thrust nappes of North Sutherland, Scotland: insights from ${ }^{40} \mathrm{Ar} /{ }^{39} \mathrm{Ar}$ and $\mathrm{Rb}-\mathrm{Sr}$ chronology. Journal of the Geological Society, London, 158, 501-512.

Elliott, D. \& Johnson, M. R. W. 1980. Structural evolution of the northern part of the Moine thrust belt, NW Scotland. Transactions of the Royal Society of Edinburgh: Earth Sciences, 71, 69-96.

Evans, D. J. 1984. Petrofabric studies in the Moine Thrust Zone, North Sutherland. Unpublished PhD thesis. University of London.

Evans, D. J. \& White, S. H. 1984. Microstructural and fabric studies of the Moine rocks of the Moine Nappe, Eriboll, NW Scotland. Journal of Structural Geology, 6, 369-389.

EWING, J. A. 1880. On certain effects of stress on soft iron wires (first paper). Proceedings of the Royal Society, 30, 510-515.

Ewing, J. A. \& Rosenhain, W. 1899. The crystalline structure of metals (first paper). Philosophical Transactions of the Royal Society, A193, 353-391.

Ewing, J. A. \& Rosenhain, W. 1901. The crystalline structure of metals (second paper). Philosophical Transactions of the Royal Society, A195, 279-302.

Fleet, C. \& Withers, C. W. J. 2008. A Scottish paper landscape - the Ordnance Survey six-inch 1st edition maps of Scotland, 1843-1882. < http://www.nls. uk/maps/os/6inch/os_info1.html $>$ (accessed 7 July 2009).

Freeman, S. R., Butler, R. W. H., Cliff, R. A. \& ReX, D. C. 1998. Direct dating of mylonite evolution: a multi-disciplinary geochronological study from the Moine Thrust Zone, NW Scotland. Journal of the Geological Society, London, 155, 745-758.

GEIKIE, A. 1882. Textbook of Geology (1st edition). Macmillan, London.

GEIKIE, A. 1884. The crystalline rocks of the Scottish Highlands. Nature, 30, 29-31.

GeIKIE, A. 1885. Textbook of Geology (2nd edition). Macmillan, London.

GeIKIE, A. 1893. Textbook of Geology (3rd edition). Macmillan, London.

GeikiE, A. 1903. Textbook of Geology (4th edition). Macmillan, London.

GEIKIE, A. 1905. Structural and Field Geology. Oliver \& Boyd, Edinburgh.

GEIKIE, A. 1908. Anniversary address of the president. Proceedings of the Geological Society, London, 64, 1-cxxv.

GeIKIE, A. 1913. Mountains Their Origin, Growth and Decay. Oliver \& Boyd, Edinburgh.

GeIKIE, A. 1924. A Long Life's Work. Macmillan, London.

Geikie, A., Campbell, R. C. \& Craig, R. M. 1940. Structural and Field Geology (5th edition). Oliver \& Boyd, Edinburgh.

Geikie, A., Campbell, R. C. \& Craig, R. M. 1953. Structural and Field Geology (6th edition). Oliver \& Boyd, Edinburgh.

Grant, C. J. 1989. The kinematics and tectonic significance of ductile shear zones within the Northern Highland Moine. Unpublished $\mathrm{PhD}$ thesis, University of Liverpool.

HICKS, H. 1878. On the metamorphic and overlying rocks in the neighbourhood of Loch Maree, Ross-shire. Quarterly Journal of the Geological Society, London, 34, 811-818.

Higgins, M. R. W. 1971. Cataclastic rocks. United States Geological Survey Professional Paper, 687, $1-97$.

Holdsworth, R. E. 1989. The geology and structural evolution of a Caledonian fold and thrust zone, Kyle of Tongue region, Sutherland, N. Scotland. Journal of the Geological Society, London, 146, 809-823.

Holdsworth, R. E. 1990. Progressive deformation structures associated with ductile thrusts in the Moine Nappe, Scotland. Journal of Structural Geology, 12, $443-452$.

Holdsworth, R. E. \& GRAnT, C. J. 1990. Convergencerelated 'dynamic spreading' in a mid-crustal ductile thrust zone: a possible orogenic wedge model. In: KNIPE, R. J. \& RutTer, E. H. (eds) Deformation Mechanisms, Rheology and Tectonics. Geological Society, London, Special Publications, 54, 491-500.

Holdsworth, R. E., Strachan, R. A., Alsop, G. I., Grant, C. J. \& Wilson, R. W. 2006. Thrust sequences and the significance of low-angle, out-ofsequence faults in the northern most Moine Nappe and Moine Thrust Zone, NW Scotland. Journal of the Geological Society, London, 163, 801-814. 
Holdsworth, R. E., Alsop, G. I. \& Strachan, R. A. 2007. Tectonic stratigraphy and structural continuity of the northernmost Moine Thrust Zone and Moine Nappe, Scottish Caledonides. In: RIES, A. C., Butler, R. W. H. \& Graham, R. H. (eds) Deformation of the Continental Crust: The Legacy of Mike Coward. Geological Society, London, Special Publications, 272, 121-142.

HowARTH, R. J. \& LEAKE, B. E. 2002. The Life of Frank Coles Phillips (1902-1982) and the Structural Geology of the Moine Petrofabric Controversy. Geological Society, London, Memoirs, 23.

HSU, K. J. 1955. Granulites and mylonites of the region about Cucamonga and San Antonio Canyons, San Gabriel Mountains, California. University of California Publications in Geological Sciences, 30, $223-352$.

HudDleston, W. H. 1879. On the controversy respecting the gneiss rocks of the North-west Highlands. Proceedings of the Geologists' Association, 6, 47-79.

Huddleston, W. H. 1882. First impressions of Assynt. Geological Magazine, decade 2, 9, 390-399.

HutTon, D. H. W. 1979. Tectonic slides: a review and reappraisal. Earth-Science Reviews, 15, 151-172.

Johnson, M. R. W. 1957. The structural geology of the Moine Thrust Zone in Coulin Forest, Wester Ross. Quarterly Journal Geological Society, London, 113, 241-270.

Johnson, M. R. W. 1965. The Moine thrust: a discussion. Journal of Geology, 73, 672-675.

Johnson, M. R. W. 1967. Mylonite zones and mylonite banding. Nature, 213, 246-247.

Johnson, M. R. W., Kelly, S. P., Oliver, G. J. H. \& WINTER, D. A. 1985. Thermal effects and timing of thrusting in the Moine Thrust Zone. Journal of the Geological Society, London, 142, 863-874.

KeLLEY, S. P. 1988. The relationship between K-Ar ages, mica grainsizes and movement on the Moine Thrust Zone. Journal of the Geological Society, London, 145, $1-10$.

KJERULF, T. 1885. Grundfjeld profilet red Mjosens sydende. Nyt Mag. Xaturvidenskaberne, 29, 215-294.

KNIPE, R. J. 1990. Microstructural analysis and tectonic evolution in thrust systems: examples from the Assynt area of the Moine Thrust Zone, Scotland. In: Barber, D. J. \& Meredith, P. G. (eds) Deformation Processes in Minerals, Ceramics and Rocks. Unwin Hyman, London, 228-261.

KNOPF, E. B. 1931. Retrogressive metamorphism and phyllonitization. American Journal of Science, 21, $1-27$.

Krabbendam, M., Prave, T. \& Cheer, D. 2008. A fluvial origin for the Neoproterozoic Morar Group, NW Scotland: implications for Torridon-Morar Group correlation and the Grenville Orogen foreland basin. Journal of the Geological Society, London, 165, 379-394.

LAPWORTH, C. 1878. The Moffat Series. Quarterly Journal of the Geological Society, London, 34, 240-346.

LAPWORTH, C. 1879. On the tripartite classification of the Lower Paleozoic rocks. Geological Magazine, Decade 2, 6, 1-15.
LAPWORTH, C. 1883. The secret of the Highlands. Geological Magazine, decade 2, 10, 120-128, 193 194, 335-344.

LAPWORTH, C. 1884. On the structure and metamorphism of the rocks of the Durness-Eriboll area. Proceedings of the Geologists' Association, 8, 438-442.

LAPWORTH, C. 1885 a. The highland controversy in British Geology: its causes, course and consequences. Nature, 32, 558-559.

LAPWORTH, C. $1885 b$. On the close of the highland controversy. The Geological Magazine, Decade 3, 2, 97-106.

LAPWORTH, C. 1899. An Intermediate Textbook of Geology. Blackwood, Edinburgh.

LAW, R. D. \& JoHnson, M. R. W. 2010. Microstructures and crystal fabrics of the Moine thrust zone and the Moine nappe: history of research and changing tectonic interpretations. In: LAW, R. D., BUTLER, R. W. H., Holdsworth, R. E., Krabbendam, M. \& STRACHAN, R. A. (eds) Continental Tectonics and Mountain Building: The Legacy of Peach and Horne. Geological Society, London, Special Publications, 335, 443-503.

LAW, R. D., Knipe, R. J. \& Dayan, H. 1984. Strain path partitioning within thrust sheets: microstructural and petrofabric variations evidence from the Moine Thrust Zone at Loch Eriboll, northwest Scotland. Journal of Structural Geology, 6, 477-497.

LAW, R. D., CASEY, M. \& KNIPE, R. J. 1986. Kinematic and tectonic significance of microstructures and crystallographic fabrics within quartz mylonites from Assynt and Eriboll regions of the Moine Thrust Zone, NW Scotland. Transactions of the Royal Society of Edinburgh: Earth Sciences, 77, 99-126.

LIPS, A. L. W. 1998. Temporal constraints on the kinematics of an orogen; syn- to post orogenic extensional collapse of the Northern Agean region. Geologica Ultraiectina, 166, 1-222.

Lips, A. L. W., WiJbrans, J. R. \& White, S. H. 1999. New insights from ${ }^{40} \mathrm{Ar} /{ }^{39} \mathrm{Ar}$ laserprobe dating of white mica fabrics from the Pelion Massif, Pelogonian Zone, Internal Hellenides, Greece: Implications for the timing of metamorphic episodes and orogenic in the Aegean region. In: DuRAND, B., Jolivet, F. L., Horvath, F. \& Serranne, M. (eds) The Mediterranean Basins: Tertiary Extension within the Alpine Orogen. Geological Society, London, Special Publications, 156, 457-473.

MaCGREgOR, A. C. 1948. Resemblances between Moine and 'Sub-Moine' metamorphic sediments in the western Highlands of Scotland. Geological Magazine, 85, 265-275.

MacGregor, A. C. 1952. Metamorphism in the Moine Nappe of Northern Scotland. Transactions of the Edinburgh Geological Society, 15, 241-257.

MCClay, K. R. \& CowARD, M. P. 1981. The Moine Thrust zone: an overview. In: MCCLAY, K. R. \& PrICE, N. J. (eds) Thrust and Nappe Tectonics. Geological Society, London, Special Publications, 9, 241-260.

MCIntyre, D. B. 1954. The Moine Thrust - its discovery, age and tectonic significance. Proceedings of the Geologists' Association, 65, 203-223. 
MCLACHLAN, G. R. 1953. The bearing of rolled garnets on the concept of the b-lineation in Moine rocks. Geological Magazine, 90, 172-176.

MEHL, R. F. 1948. A Brief History of the Science of Metals. American Institute of Mining and Metallurgical Engineers, New York.

MEllard READE, T. 1886. The Origin of Mountain Ranges Considered Experimentally, Structurally, Dynamically and in Relation to their Geological History. Taylor \& Francis, London.

Miall, T. 1869. Experiments on the contortion of mountain limestone. Geological Magazine, 6, 505-506.

MUIR, R. J. 1899. On the recovery of iron from overstrain. Philosophical Transactions of the Royal Society, A193, 1-46.

MOORE, H. E. 1980. Rock textures and microstructures related to cataclastic processes. Unpublished $\mathrm{PhD}$ thesis, University of London.

Murchison, R. I. 1839. The Silurian System. John Murray, London.

MuRChISON, R. I. 1848. On the geological structure of the Alps, Appenines and Carpathians, more especially to prove a transition from Secondary to Tertiary rocks, and development of Eocene deposits in southern Europe. Quarterly Journal of the Geological Society, London, 5, 157-312.

Murchison, R. I. 1854. Siluria: A History of the Oldest Rocks Known Containing Organic Remains, with a Brief Sketch of the Distribution of Gold Over the Earth. John Murray, London.

MURCHISON, R. I. 1858a. On the succession rocks in the northern highlands, from the oldest gneiss, through strata of Cambrian and lower Silurian age, to the Old Red Sandstone inclusive. Quarterly Journal of the Geological Society, London, 15, 501-504.

MuRCHISON, R. I. $1858 \mathrm{~b}$. On the succession of the older rocks in the northernmost counties of Scotland; with some observations on the Orkney and Shetland Islands. Quarterly Journal of the Geological Society, London, 15, 353-403.

MurCHISON, R. I. 1859. Supplemental observations on the order of the ancient stratified rocks of the north of Scotland, and their associated eruptive rocks. Quarterly Journal of the Geological Society, London, 16, 215-241.

Murchison, R. I. \& GeIKIE, A. 1861a. On the altered rocks of the western islands of Scotland and northwestern and western highlands. Quarterly Journal of the Geological Society, London, 18, 171-232.

Murchison, R. I. \& GeIKIE, A. $1861 b$. On the coincidence between stratification and foliation in the crystalline rocks of the Scottish. Quarterly Journal of the Geological Society, London, 18, 232-240.

MurChison, R. I. \& GEIKIE, A. 1862. First Sketch of a Geological Map of Scotland with Explanatory Notes. W. \& A. K. Johnston, and W. Blackwood \& Sons, Edinburgh.

NiCOL, J. 1856. On the red sandstone and conglomerate, and superimposed quartz-rocks, limestones, and gneiss of the north-west coast of Scotland. Quarterly Journal of the Geological Society, London, 13, 17-39.

NiCOL, J. 1858. Geological Map of Scotland from the Most Recent Authorities \& Personal Observations. A. K. Johnston, Edinburgh.
NICOL, J. 1860. On the structure of the north-western highlands, and the relations of the gneiss, red sandstone, and quartzite of Sutherland and Ross-shire. Quarterly Journal of the Geological Society, London, 17, 85-113.

Oldroyd, D. R. 1990. The Highlands Controversy. The University of Chicago Press, Chicago.

Ord, A. \& Christie, J. M. 1984. Flow stresses from microstructures in mylonitic quartzites of the Moine thrust zone, Assynt area, Scotland. Journal of Structural Geology, 6, 639-654.

PAGE, D. 1870. Geology for General Readers. Blackwoods, Edinburgh.

PAGE, D. 1877. Introductory Textbook of Geology (11th edition). Blackwoods, Edinburgh.

PAGE, D. \& LAPWORTH, C. 1888. Introductory Textbook of Geology (12th edition). Blackwood, Edinburgh.

Passchier, C. W. \& Trouw, R. A. J. 2005. Microtectonics (2nd edition). Springer, Berlin.

PEACH, B. N. \& HoRnE, J. 1884. Report on the geology of north-west of Sutherland. Nature, 31, 31-35.

PEACH, B. N. \& HoRnE, J. 1885. The geology of Durness and Eriboll, with particular reference to the highland controversy. Nature, 32, 558.

PEACH, B. N. \& HoRne, J. 1914. Guide to the Geological Model of the Assynt Mountains. Geological Survey Office, London.

PeACH, B. N. \& Horne, J. 1930. Chapters on the Geology of Scotland. Oxford University Press, London.

Peach, B. N., Horne, J., Gunn, W., Clough, C. T., Hinxman, L. \& CAdell, H. M. 1888. Report on recent work of the Geological Survey in the northwest Highlands of Scotland. Quarterly Journal of the Geological Society, London, 64, 379-441.

Peach, B. N., Horne, J., Gunn, W., Clough, C. T. \& HinXman, L. 1907. The Geological Structure of the Northwest Highlands of Scotland. Memoirs of the Geological Survey of Great Britain. HMSO, Glasgow.

PhILIPS, F. C. 1937. A fabric study of the Moine schists and some associated rocks. Quarterly Journal Geological Society, London, 93, 581-616.

Philips, F. C. 1945. The micro-fabric of the Moine schists. Geological Magazine, 82, 205-222.

Powell, D., BAIRD, R. W., CARNLEY, N. R. \& JORDAN, P. J. 1981. The metamorphic environment of the Sgurr Beag Slide, a major crustal displacement zone in Proterozoic Moine rocks of Scotland. Journal of the Geological Society, London, 138, 661-673.

QUARRELL, A. G. 1964. Metallography - a hundred years after Sorby. The Iron and Steel Institute, Special Report, 80, 1-36.

RAthbone, P. A. \& HarRis, A. L. 1980. Basement-cover relationships at Lewisian inliers in the Moine rocks. In: Harris, A. L., Holland, C. H. \& Leake, B. E. (eds) The Caledonides of the British Isles Reviewed. Geological Society, London, Special Publications, 8, 101-107.

READ, H. H. 1931. The geology of central Sutherland (sheets 108-109). Memoir of the Geological Survey, Scotland.

READ, H. H. 1934. Age problems with the Moine Series of Scotland. The Geological Magazine, 21, 302-317.

READ, H. H. 1951. Mylonitisation and cataclasis in acidic dykes in the Insch (Aberdeenshire) gabbro and its 
aureole. Proceedings of the Geologists' Association, 62, 237-247.

READ, H. H. \& WATSON, J. 1962. Introduction to Geology. Volume 1, Principles. Macmillan, London.

Rudwick, M. J. S. 1985. The Great Devonian Controversy: The Shaping of Scientific Knowledge Among Gentlemanly Specialists. University of Chicago Press.

RutTer, R. H. \& White, S. H. 1979. The microstructure and rheology of fault gouges produced experimentally under wet and dry conditions. Bulletin Mineralogie, 102, $101-109$.

SANDER, B. 1970. An Introduction to the Study of the Fabrics of Geological Bodies. English translation by Phillips, F. C. \& Windsor, G. Pergamon, Oxford.

SCHMID, S. M. \& HANDY, M. R. 1991. Towards a genetic classification of fault rocks: geological usage and tectonophysical implications. In: MUlLER, D. W., McKenzie, J. \& Weissert, H. (eds) Controversies in Modern Geology. Academic Press, London.

SECORD, J. A. 1986. Controversies in Victorian Geology: The Cambrian-Silurian Dispute. Princeton University Press.

SiBSON, R. H. 1977. Fault rocks and fault mechanisms. Quarterly Journal of the Geological Society, London, 133, 191-213.

Smallman, R. E. 1985. Modern Physical Metallurgy (4th edition). Butterworth-Heinnemann, Oxford.

Smulikowski, W., Desmons, J., Fettes, D. J., Harte, B., Sussi, F. P. \& Schmid, J. A. 2007. Types, Grade and Facies of Metamorphism. IUGS Subcommission on the Systematics of Metamorphic Rocks (SCMR).

SNOKE, A. W. \& Tullis, J. 1998. An overview of fault rocks. In: SNOKE, A. W., Tullis, J. \& TodD, V. R. (eds) Fault-Related Rocks: A Photographic Atlas. Princeton University Press, Princeton, NJ, 3-18.

Soper, N. J. \& Wilkinson, P. 1975. The Moine Thrust and Nappe at Loch Eriboll, Sutherland. Scottish Journal of Geology, 11, 339-359.

Sorby, H. C. 1853 . On the origin of slaty cleavage. The New Philosopical Journal (Edinburgh), 55, 137-148.

SORBY, H. C. 1856 . On the theory of the origin of slaty cleavage. Philosopical Magazine, 12, 127-129.

SORBY, H. C. 1864 . On the microscopical structure of meteorites. Proceedings of the Royal Society, 13, 333-334.

SoRBY, H. C. 1879 . The anniversary address of the president. Proceedings of the Geological Society, London, 35, 56-95.

SORBY, H. C. 1886 . On the application of very high powers to the study of the microstructural structure of steel. Journal of the Iron and Steel Institute, 32, 140-147.

SoRBY, H. C. 1887. On the microscopical structure of iron and steel. Journal of the Iron and Steel Institute, 33, 255-288.

SORBY, H. C. 1908. On the application of quantitative methods of the structure and history of rocks. Quarterly Journal of the Geological Society, London, 64, $171-233$.

SPRY, A. 1969. Metamorphic Textures. Pergamon, Oxford.

Strachan, R. A., Smith, M., Harris, A. L. \& Fettes, D. J. 2002. The Northern Highlands and Grampian terranes. In: TREWIN, N. H. (ed.) The Geology of Scotland. Geological Society, London, 81-148.
TANNer, P. W. G. 1971. The Sgurr Beag Slide - a major break within the Moinian of the Western Highlands of Scotland. Quarterly Journal of the Geological Society, London, 126, 435-463.

TAYLOR, G. I. 1934a. The mechanism of plastic deformation of crystals. Part 1 - Theorectical. Proceedings of the Royal Society, A145, 362-387.

TAYLOR, G. I. 1934b. The mechanism of plastic deformation of crystals. Part 2 - Comparison with observations. Proceedings of the Royal Society, A145, $388-404$

TAYLOR, G. I. 1934c. The strength of rock salt. Proceedings of the Royal Society, A145, 405-415.

TAYLOR, G. I. 1934d. Faults in a material which yields to shear stress while retaining its volume elasticity. Proceedings of the Royal Society, A145, $1-19$.

TEALL, J. J. H. 1885. The metamorphosis of dolerite into hornblende-schist. Quarterly Journal of the Geological Society, London, 41, 133-145.

TEALL, J. J. H. 1886. On the metamorphosis of the Lizard gabbros. The Geological Magazine, Decade 3, 3, 480-489.

TEALL, J. J. H. 1887. On origin of certain banded gneisses. The Geological Magazine, Decade 3, 4, 484-493.

TeAll, J. J. H. 1888. Notes on the rock-specimens collected by Mr. Fox from the islands of the Lizard Head. Quarterly Journal of the Geological Society, London, 44, 314-317.

TEALL, J. J. H. 1902. Anniversary address of the President. Proccedings of the Geological Society, London, $\mathbf{5 8}$ 1xiii-1xviii.

Teall, J. J. H. 1918. Dynamic metamorphism. A review, mainly personal. Proceedings of the Geologists' Association, 39, 1-15.

Thigpen, J. R., LAw, R. D., Lloyd, G. E., Brown, S. J. \& COOK, B. 2010. Deformation temperatures, vorticity of flow and strain symmetry in the Loch Eriboll mylonites, NW Scotland: Implications for the kinematic and structural evolution of the northernmost Moine thrust zone. In: LAW, R. D., BUtLeR, R. W. H., Holdsworth, R. E., KrabBendam, M. \& Strachan, R. A. (eds) Continental Tectonics and Mountain Building: The Legacy of Peach and Horne. Geological Society, London, Special Publications, 335, 623-662.

TRESCA, H. 1878. On further applications of the flow solids. Proceedings of the Institute of Mechanical Engineers, 30, 301-345.

Weathers, M. S., Bird, J. M., Cooper, R. F. \& Kolhstedt, D. C. 1979. Differential stress determined from deformation induced microstructures of the Moine thrust zone. Journal of Geophysical Research, 84, 7459-7509.

White, S. H. 1973a. Dislocation structures responsible for the optical effects in some naturally deformed quartzes. Journal of Materials Science, 8, 490-499.

White, S. H. 1973b. Syntectonic recrystallisation and texture development in quartz. Nature, 244 276-278.

White, S. H. 1976. Effects of strain on the microstructures, fabrics and deformation mechanisms in quartzites. Philosophical Transactions of the Royal Society, A283, 69-86. 
White, S. H. 1979a. Grain size and sub-grain size variation across a mylonite zone. Contributions to Mineralogy and Petrology, 70, 193-202.

White, S. H. 1979b. Paleo-stress estimates in the Moine Thrust Zone, Eriboll, Scotland. Nature, 280, 222-223.

WHITE, S. H. 1979c. Report of a discussion meeting on large strain deformation. Journal of Structural Geology, 1, 331-339.

White, S. H. 1998. Fault rocks from Ben Arnaboll, Moine Thrust Zone, Northwest Scotland. In: SNOKE, A. W., TUllis, J. \& TODD, V. R. (eds) Fault-Related Rocks: A Photographic Atlas. Princeton University Press, 382-391.

White, S. H. \& KNIPE, R. J. 1978. Transformation and reaction enhanced ductility in rocks. Journal of the Geological Society, London, 135, 513-516.
White, S. H., Burrows, S. E., Carreras, J., Shaw, N. D. \& HuMphreYs, F. J. 1980. On mylonites in ductile shear zones. Journal of Structural Geology, 2, 175-187.

White, S. H., Evans, D. J. \& Zhong, D. L. 1982. Fault rocks of the Moine Thrust Zone: microstructures and textures of selected mylonites. Textures and Microstructures, 5, 33-61.

WiLson, G. 1952. A quartz vein system in the Moine Series near Melness, A'Mhoine, North Sunderland, and its tectonic significance. Geological Magazine, 89, $141-144$.

WILSON, G. 1953. Mullion and rodding structures in the Moine Series of Scotland. Proceedings of the Geologists' Association, 64, 118-151.

WISE, D. U., DUNN, E. ET AL. 1984. Fault-related rocks: suggestions for terminology. Geology, 12, 391-394. 